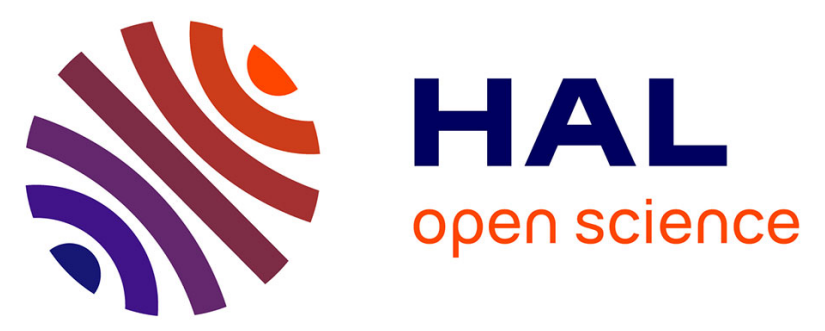

\title{
The Neogene Xiyu Formation, a diachronous prograding gravel wedge at front of the Tianshan: Climatic and tectonic implications
}

Julien Charreau, Charles Gumiaux, Jean-Philippe Avouac, Romain Augier, Yan Chen, Laurie Barrier, Stuart A. Gilder, Stéphane Dominguez, Nicolas Charles, Qingchen Wang

\section{To cite this version:}

Julien Charreau, Charles Gumiaux, Jean-Philippe Avouac, Romain Augier, Yan Chen, et al.. The Neogene Xiyu Formation, a diachronous prograding gravel wedge at front of the Tianshan: Climatic and tectonic implications. Earth and Planetary Science Letters, 2009, 287, pp.298-310. 10.1016/j.epsl.2009.07.035 . insu-00414151

HAL Id: insu-00414151

https://hal-insu.archives-ouvertes.fr/insu-00414151

Submitted on 16 Sep 2009

HAL is a multi-disciplinary open access archive for the deposit and dissemination of scientific research documents, whether they are published or not. The documents may come from teaching and research institutions in France or abroad, or from public or private research centers.
L'archive ouverte pluridisciplinaire HAL, est destinée au dépôt et à la diffusion de documents scientifiques de niveau recherche, publiés ou non, émanant des établissements d'enseignement et de recherche français ou étrangers, des laboratoires publics ou privés. 


\title{
The Neogene Xiyu Formation, a diachronous prograding gravel wedge at front of the Tianshan: Climatic and tectonic implications
}

\author{
Julien Charreau $^{\text {a, b, }}$, Charles Gumiaux ${ }^{\text {c, }}$, Jean-Philippe Avouac ${ }^{\text {a, 1, }}$, Romain Augier, ${ }^{\text {, }}$, \\ Yan Chen $^{\text {c, 2, }}$, Laurie Barrier ${ }^{\mathrm{d}, ~ 3,}$, Stuart Gilder $^{\mathrm{e}}$, Stéphane Dominguez ${ }^{\mathrm{f}}$,, , Nicolas \\ Charles $^{\mathrm{c}, 2}$ and Qingchen Wang ${ }^{\mathrm{g}}$
}

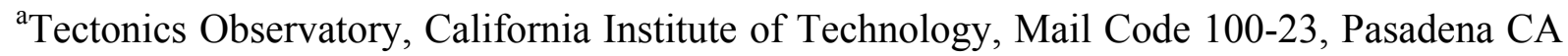
91125, USA

${ }^{\mathrm{b}}$ Centre de Recherche Pétrographique et Géochimique, 15 rue Notre Dame des Pauvres, 54501 Vandoeuvre lès Nancy, France

${ }^{\mathrm{c}}$ Université d'Orléans, CNRS/INSU, Université François Rabelais - Tours, Institut des Sciences de la Terre d'Orléans - UMR 6113, Campus Géosciences, 1A, rue de la Férollerie, 45071 Orléans Cedex 2, France

${ }^{\mathrm{d}}$ Institut de Physique du Globe de Paris, 4 place Jussieu, 75252 Paris Cedex 05 France

${ }^{\mathrm{e}}$ Ludwig Maximilians University, Department of Earth and Environmental Sciences, Geophysics Section, Theresienstrasse 41, 80333 Munich, Germany

${ }^{\mathrm{f}}$ Laboratoire Dynamique de la Lithosphère; UMR CNRS/UMII 5573, Bâtiment 22 [cc. 60] Place Bataillon, 34095 Montpellier Cedex, France

${ }^{\mathrm{g}}$ State Key Laboratory of Lithospheric Evolution, Institute of Geology and Geophysics, Chinese Academy of Sciences, Beijing 100029, China

\begin{abstract}
The Tarim and Junggar basins in central Asia are capped by a thick pile of conglomerates, called the Xiyu Formation, that are commonly linked to a change in climate and/or accelerated uplift near the Plio-Pleistocene boundary. In order to better understand their origin and significance, we carried out a combined structural and magnetostratigraphic study in the Quilitage syncline (southern Tianshan), where the base of the Xiyu conglomerates is observed at both sides of the syncline. A balanced cross-section shows that, even at a local-scale, the base of the Xiyu conglomerates cannot be regarded as a single continuous stratigraphic layer. On the southern flank of the Quilitage syncline, we collected 172 samples collected for magnetostratigraphic dating identify 17 polarity chrons that date the new section from 5.2 to $\sim 1.7 \mathrm{Ma}$ and constrain the base of the Xiyu conglomerate here at $\sim 1.7 \mathrm{Ma}$. This is $4.2 \mathrm{Ma}$ younger than the age of the Xiyu previously found on the northern limb of the same syncline. Together with other magnetostratigraphic studies carried out around the Tianshan, our study unambiguously demonstrates that the onset of deposition of the Xiyu conglomerates is diachronous, and that the conglomerates are systematically younger toward the basin. Consequently, the Xiyu Formation should not be considered as a chronostratigraphic marker related to any particular tectonic or climatic event, but is instead a prograding gravel wedge that has prograded over the underthrusting forelands. A synthesis of chronologic and structural results yields progradation rates over the last $10 \mathrm{Ma}$ on the order of $\sim 2.0 \mathrm{~mm} / \mathrm{yr}$ and $\sim 3.9 \mathrm{~mm} / \mathrm{yr}$ south and north of the Tianshan Mountains respectively. These rates are
\end{abstract}


comparable to the shortening rate across the Tianshan range, suggesting that underthrusting is the main factor governing the progradation rate of the Xiyu Formation.

Keywords: Xiyu Formation; magnetostratigraphy; Tianshan; gravel wedge progradation; shortening rates

\section{Introduction}

As a mountain range grows surface processes become more active and result in a mass transfer from the uplifted zone to the flanking lowlands. This mass transfer depends on climate and can significantly influence tectonics by contributing to uplift or subsidence through isostatic compensation ([Beaumont et al., 1988], [Cobbold et al., 1993], [Molnar and England, 1990], [Schlunegger et al., 1997] and [Whipple and Meade, 2006]), and bears on deformation and thermal structure by its effect on heat advection ([Avouac and Burov, 1996], [Batt and Braun, 1997], [Beaumont et al., 1994] and [Jamieson and Beaumont, 1988]). Mountain building is, therefore, a complex process resulting from coupling between tectonic deformation, climate and surface processes ([Avouac and Burov, 1996], [Burbank, 1992], [Koons, 1987] and [Molnar and England, 1990]). Foreland basin sediments thus provide a record of this process in which the respective influence of tectonics and climate is often difficult to untangle.

The Tarim and Junggar basins in central Asia (Fig. 1) accumulate eroded materials from the nearby Tianshan mountains. As closed intracontinental basins, their thick Cenozoic sedimentary cover represents prime examples where one can estimate the mass eroded from the mountain and thus quantify transfer processes. Folding and thrusting on both the northern and southern piedmonts expose exceptional outcrops of the sediments at numerous sections. In both basins, the top of the sedimentary fill consists of remarkably thick dark gravels, called the Xiyu Formation (Fig. 1 and Fig. 2), that one can be used to quantify mass transfer across the basins.

In 1953, Chinese geologist C.L. Fang and his colleagues found a vertebrate fossil of Equus sanmeniensis in the Anjihaihe section at the transition between the Dushanzi and the Xiyu Formations (Fig. 1). This fossil was dated from 2.48 Ma to the early Pleistocene ([Chen et al., 1994], [Feng and Dai, 2004], [Gaboardi et al., 2005] and [Zhu et al., 2004]). Xiyu-type conglomerates are widely distributed along the periphery of the major mountain ranges in central Asia (Fig. 1), and are commonly lithostratigraphically assigned to the early Pleistocene Xiyu Formation throughout central Asia ([Huang et al., 2006], [Sun et al., 2007] and [Sun et al., 2004]). The age designation stemming from the finding of E. sanmeniensis in the Anjihaihe section has thus had considerable impact. Some workers argue that the conglomerate would signify a late Plio-Pleistocene acceleration in uplift of the Tianshan (Burchfiel et al., 1999) or of the Tibet Plateau (Zheng et al., 2000). Alternatively, since the Plio-Pleistocene transition is characterized by a transition to widespread glaciation after a relatively warm period during the Mio-Pliocene ([Zachos et al., 2001] and [Zhang et al., 2001]), other workers argue that the Xiyu Formation must be linked to climate change ([Liu et al., 1996] and [Zhang et al., 2001]).

Recent magnetostratigraphic studies show that the basal age of the Xiyu conglomerate could be much older (by up to $\sim 15 \mathrm{Ma}$ ) than the early Pleistocene ([Charreau et al., 2009], [Charreau et al., 2005] and [Heermance et al., 2007]). However, others studies still assume a Pleistocene age ([Huang et al., 2006], [Sun et al., 2007] and [Sun et al., 2004]). As the studied 
localities are often far apart and because the definition of the Xiyu Formation is loose, the depositional age and the origin of the Xiyu conglomerates remain a matter of controversy. Resolving this debate (e.g. Charreau et al., 2008b) would bring important implications regarding regional tectonics and late Cenozoic climate change.

The purpose of this paper is, therefore, to clarify the definition of the Xiyu Formation and accurately determine its age range. Our analysis is based on existing magnetostratigraphic constraints and new results acquired from a section along the Yaha River, in the southern Tianshan piedmont, which, thanks to a singular tectonic setting, unambiguously demonstrates the diachronism of the Xiyu conglomerates at a local-scale.

Hereafter, we first give an overview of the regional geological setting. Next, we propose a strict sedimentological definition of the Xiyu Formation - that should provide a basis for future work in the region - and then move onto the presentation of the results with the magnetostratigraphic dating of the Yaha section. Finally we discuss the nature, tectonic and climatic significance of the Xiyu conglomerates.

\section{Geological setting of the Tianshan range}

The Tianshan is a 2500-km-long tectonically active mountain range with an average altitude of $2500 \mathrm{~m}$ and summits reaching up to $7000 \mathrm{~m}$. Its geology consists of Paleozoic rocks related to a long-lived Island Arc and subduction/collision history that started during the Devonian and ended during the Permian time ([Burtman, 1975], [Charvet et al., 2007], [Gao et al., 1998], [Lin et al., 2008], [Wang et al., 2008] and [Windley et al., 1990]). The present high topography mainly owes its origin to the Cenozoic reactivation of the range during the Oligocene to late Miocene ([Avouac et al., 1993], [Bullen et al., 2003], [Bullen et al., 2001], [Dumitru et al., 2001], [Hendrix et al., 1994], [Métivier and Gaudemer, 1997], [Sobel et al., 2006], [Sobel and Dumitru, 1997] and [Windley et al., 1990]), under the influence of the ongoing India-Asia collision. The Tianshan range is sandwiched between two large intracontinental basins (Fig. 1) that contain the eroded materials from the uplifting range.

\section{Geology of the piedmonts}

Both piedmonts are tectonic wedges composed of fold and thrust belts where early Mesozoic to Quaternary sediments that were initially deposited in the foreland basin, are now overthrusted and well exposed along numerous north-south-trending rivers (e.g. Kuitun He, Jingou He or Yaha, Fig. 1b and c). During the 1990s, several studies focused on the structural analysis of the Tianshan piedmonts (e.g. [Avouac et al., 1993] and [Burchfiel et al., 1999]). More recently, numerous seismic line profiles made for exploration of gas-oil resources have greatly improved our knowledge of the deep framework of the basins (e.g. [Charreau et al., 2008a], [Heermance et al., 2007] and [Hubert-Ferrari et al., 2007]). We focused our study in two areas, on both sides of the range: (1) in the northern Tianshan, west of Urumqi, where the piedmont consists of three main fold and thrust sequences that are respectively offset in a left lateral sense from south to north (Fig. 1b), (2) in the southern Tianshan piedmont is a $2000 \mathrm{~km}$-long tectonic wedge extending from the Kuche basin to the Kashi area. Our study was carried out in the Kuche area where two anticlines can be recognized: the Quilitage anticline and the more frontal Yakeng anticline (Fig. 1c). Seismic imaging defines the Quilitage anticline as a $225 \mathrm{~km}$-long fold bend-fault while the Yakeng anticline may be seen as a detachment fold (see seismic line in Fig. 4 from Hubert-Ferrari et al. (2007)). Between 
these anticlines and the high range, the piedmont contains several other folds and thrusts which mainly involve Paleozoic to Mesozoic sediments.

\section{Definition of the Xiyu Formation}

The Xiyu conglomerates were first described by Obruchev in the 1930s. Later on, T. K. Huang later described their lithology in more detail and classified the Xiyu (Western domain in Chinese) Formation as all piedmont-type, conglomeratic layers composed of dark-gray to brown-colored, coarse $(3$ to $>30 \mathrm{~cm}$ ) and thick $(50$ to $3200 \mathrm{~m})$ deposits that are intercalated with scarce yellow sandstone and mudstone layers (Zhou et al., 2000). This description suggests the Xiyu is a coherent and continuous unit lying at the top of the sedimentary pile in most of the central Asia's foreland basins.

The Xiyu conglomerates can be, however, more rigorously characterized according to their lithology, color and sedimentary structures that typify their depositional environment. They consist of homolithic, clast-supported, poorly to weakly sorted, massive to horizontally- and cross-bedded conglomerates made up of pebble to blocky clasts and a coarse-grained sandy matrix. Those conglomerates are exposed in 1 to $10 \mathrm{~s}$ of meters-thick and 1000s of meterswide amalgamated strata with erosive basal boundaries. Occasionally, they contain massive to cross-bedded, medium to coarse-grained sandstones lying within 0.1 to 1 meter-thick and 1 to 10 meter-wide lenses. Despite the poor sorting of the Xiyu deposits, their horizontal trough crossbedded stratification indicate motion and deposition from grain-by-grain traction sedimentation under a unidirectional upper flow regime ([Simons et al., 1965] and [Southard and Boguchwal, 1990]). Those sediments can thus be interpreted as bed load deposits at the base of high-velocity and turbulent water flow that generate large-scale gravelly bed-forms as the bars formed into the gravely braided streams ([Gloppen and Steel, 1981], [Mack and Leeder, 1999], [Miall, 1977] and [Miall, 1978]). The Xiyu Formation implies therefore the repeated occurrences of powerful stream flows typical of gravely braided alluvial fans (Blair and McPherson, 1994; Nemec and Postma, 1993), which still exist in the Tianshan piedmont (Fig. 3).

At their base, the Xiyu conglomerates gradually covered the underlying units (e.g. the Dushanzi, Kuche, Artux and Aksu formations), which are composed of finer-grained deposits (heterolithic, clast-supported, massive and horizontal to cross-bedded conglomerates alternating with claystone, siltstone and sandstone) due to stream flows and associated overbank flows into a braided fluvial system. The transition between the Xiyu Formation and the underlying sediments can be easily recognized. It may be either gradual, 100-200 m thick on average such as at the Jingou He section (e.g. Charreau et al., 2009) with a progressive coarsening up (Fig. 2f and g, see also Heermance et al. (2007)), or sharp but without evidence of any hiatus (e.g. the Kuitun He section, see Charreau et al. (2005)). This transition probably owes its origin to a shift related to an acceleration of the basinward progradation of the Xiyu alluvial fans. A straightforward definition for the base of the Xiyu Formation is when the content of boulder-size fraction exceeds $95 \%$ in the sediments.

A similar faciological transition can be observed in the present-day depositional landscape of the Tianshan piedmonts where the limit between alluvial fan and braided rivers can be easily outlined from satellite images and/or topographic maps (Fig. 3).

Below we present chronological constraints derived first from our new geometricallyconstrained magnetostratigraphic analysis of the upper Yaha section and then from previous 
studies based on the recognition of this stratigraphic limit following the definition proposed here.

\section{Diachronous deposition of the Xiyu conglomerates in the Yaha section}

The Yaha section is located on the southern flank of the Tianshan range, about $30 \mathrm{~km}$ east of Kuche city, where the south-flowing Yaha River cuts the Quilitage anticline (Fig. 1c). In the syncline located directly north of the Quilitage anticline the contact between the Xiyu conglomerates and the underlying fine grained sandstone (Kuche Fm.) can be clearly observed in the field on both limbs in a continuous section, along the Yaha River (Fig. 2c and d). The section is continuously exposed and does not show any significant discordance or faulting. This setting represents a remarkable case where the basal age of the Xiyu Formation can be constrained at two locations along a single section. On the northern limb of the syncline, the magnetostratigraphic study of Huang et al. (2006) has yielded a basal age of the Xiyu conglomerate of 5.9 Ma (Fig. 2c). Note that in their paper Huang et al. (2006) identified the thick conglomerate as Kuche formation, but we consider it as Xiyu following the above definition. On its southern flank, Charreau et al. (2006) have magnetostratigraphically dated a 2814-m thick section, in the lower part of the series, ranging from 12.6 to $5.2 \mathrm{Ma}$, but without reaching the base of the Xiyu Formation (Fig. 4a and b).

\subsection{Structural constraints in the Quilitage syncline}

The structure of the syncline was well constrained via 29 field measurements of bedding orientation regularly distributed along a 4200-m-long section and accurately geo-referenced with GPS (Fig. 4b and c). The strike direction remains relatively constant with a mean of

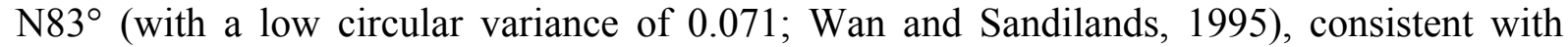
cylindrical folding. We built a section perpendicular to the mean strike with nearly all measurement sites lying at a distance less than $150 \mathrm{~m}$ from the synthetic section (Fig. 4b and c). Apparent dips were projected on this synthetic section line yet almost equal to the true values measured on the field (Fig. 4c). These structural measurements were used to compute the cumulative thicknesses along the section: the Xiyu Formation amounts to $\sim 1052 \mathrm{~m}$ on the northern limb and to only $\sim 220 \mathrm{~m}$ on the southern one.

A hand-balanced cross section is presented in Fig. 4c. Taking into account the overall measurements within the conglomerates, and in particular the ones surrounding the fold axis, the best-fit solution results in a simple, upright syncline fold with sub-parallel strata within the Xiyu formation. Such a structure has been extrapolated to depth in the section (cf. dash lines on Fig. 4c). The reference horizon (thick black line on Fig. 4c), which corresponds to the base of the Xiyu conglomerates at the southern limb, is structurally positioned far above the base of the conglomerates on the northern flank. Moreover, the difference of cumulative thicknesses of the Xiyu formation, from one limb to the other $(\sim 1052$ and $\sim 220 \mathrm{~m})$, is rather consequent It is therefore clear that the stratigraphic depth of the transition to the Xiyu conglomerates varies laterally.

Therefore, one cannot structurally extend the base of the Xiyu conglomerates through a single horizon (Fig. 4c) which strictly requires lateral sedimentological facies variations from the homolithic Xiyu conglomerates toward a finer grained heterolithic Formation (i.e. Kuche Fm.) from north to south (i.e. range toward basin). We observed these stratigraphic features at the southern contact between the Xiyu and Kuche Formations (Fig. 3d). This figure shows a lateral lithological variation within the series highlighted by thinning of the conglomerate 
beds and a relative thickening of the sandstones from north to south. Thus, from a structural viewpoint the base of the Xiyu conglomerate cannot be regarded as a synchronous and laterally-continuous, single stratigraphic layer.

\subsection{Sampling, rock magnetism and magnetostratigraphy of the upper Yaha section}

To determine the age of the base of the Xiyu Formation in the southern flank of the Quilitage syncline, we carried out a new magnetostratigraphic section to extend upward the previously published section of Charreau et al. (2006). To ensure stratigraphic continuity with the previous section, the new magnetostratigraphic section was carried out in a lateral tributary of the main Yaha River (Fig. 4b). In addition, the structural study, unraveling the cylindrical architecture of the fold allows a perfect correlation between the magnetostratigraphic and the structural sections (Fig. 4c). The new sampled section spans $1630 \mathrm{~m}$ in stratigraphic thickness spanning a horizontal distance of $5900 \mathrm{~m}$ (Fig. 4b). It begins at the top end of Charreau et al.'s (2006) section and progress upwards until reaching the contact between the Xiyu and Kuche formations. 386 cores were drilled then oriented with magnetic and sun compasses. Two or three cores per horizon were collected with an average distance between horizons of about $8 \mathrm{~m}$. Each horizon was positioned using a GPS instrument. Samples were collected in the upper part of the Kuche group were composed mainly of red-muddy sandstones intercalated with siltstone and green-gray sandstones. The average grain size becomes progressively coarse-grained upward in the sequence, until reaching the Xiyu conglomerates. As mentioned above, no stratigraphic duplication, unconformities or faults were visible either in field or in seismic images (see seismic line in Fig. 4 from Hubert-Ferrari et al. (2007)), suggesting that sedimentation was relatively continuous. Spore and pollen, such as Deltoudospora sp., Ephedripites sp. Pinuspollonites sp., have been identified and assign a Pleistocene to Pliocene age to the upper part of the Kuche group (Bureau of the Geological and the Mineral Resources of the Xinjiang Uygur Autonomous Region, 1985).

Curie point analyses show an important drop in magnetic susceptibility near $580{ }^{\circ} \mathrm{C}$, followed by a progressive decrease in susceptibility until $680^{\circ} \mathrm{C}$, signaling the presence of both magnetite and hematite (Fig. 5a). Both thermal and alternating field demagnetization yield similar results, although thermal demagnetization seemed more efficient (Fig. 5). Most samples possess two components - one at low temperatures or small peak fields $\left(<200{ }^{\circ} \mathrm{C}\right.$ or $<10 \mathrm{mT}$ ) that is north and downward directed in in-situ coordinates and does not decay toward the origin on orthogonal diagrams, and another at high temperatures or high peak fields $\left(300^{\circ}\right.$ to $680^{\circ} \mathrm{C}$ or 10 to $\left.120 \mathrm{mT}\right)$ that is of dual polarity and does decay toward the origin (Fig. 5c, d, e and f). We considered the high temperature/field component as the characteristic remanent direction (ChRM).

For the about 200 samples we demagnetized, 185 possess a stable high temperature/field component, identified as the ChRM. 52 samples have normal polarities with an average of $D=2.8^{\circ}, I=54.5^{\circ}, \alpha_{95}=3.8^{\circ}$, while 103 samples have reversed polarities with an average of $D=177.4^{\circ} I=58.8^{\circ}, \alpha_{95}=3.3^{\circ}$. The remaining 30 samples lie within reversal boundaries and their directions were likely acquired in transitional fields. The reversal test is positive (Class B, McFadden and McEhlinny (1990)). Moreover, the lower sequence in Charreau et al. (2006) passed the fold test, so we conclude, that the high temperature/field component represents a primary remanent magnetization. 
A magnetostratigraphic sequence was established from 172 samples (horizons) possessing the high temperature/field component which defined nine normal (a to i) and eight reverse (1 to 8) polarity chrons (Fig. 6a, b and c), with each chron being defined by at least two samples from two different sedimentary horizons, except for the reverse chron 1 with only one sample. We correlated the magnetostratigraphic sequence to the Lourens et al. (2004) reference-scale (Fig. 6d) continuing from the top of the section of Charreau et al. (2006) at 5.2 Ma. Fig. 6e represents our preferred correlation, which provides an almost unique fit in terms of interval number and relative duration. The only doubt in the correlation concerns the reverse chron 1 defined by just one sample. Toward the top of the section, sedimentation becomes coarser and it becomes harder to sample suitably fine-grained material within the coarse conglomerates. The magnetic remanence becomes less stable as well. That is why the number of samples with ChRM directions decreases toward the top. Despite this, the correlation appears robust and delimits the sampled sediments in time from 5.2 to $1.7 \mathrm{Ma}$ with a remarkably stable sedimentary accumulation rate of $0.48 \pm 0.21 \mathrm{~mm} / \mathrm{yr}$ (Fig. 6e). This new section is perfectly continuous with the underlying section (Fig. 7) of Charreau et al. (2006) which thus strongly supports their original correlation and not the reinterpretation of Huang et al. (2006) as explained in Charreau et al. (2008b). This $\sim 4500$-m-thick total section ranges from 12.6 to 1.7 Ma. It identifies a rather young, 1.7 Ma, age for the base of the Xiyu conglomerates that lie on top of the section and shows a distinct accumulation rate change at $\sim 11 \mathrm{Ma}$. A similar acceleration rate was also observed on the north flank of the Tianshan range at $\sim 11 \mathrm{Ma}$ (Charreau et al., 2008a). Hubert-Ferrari et al. (2007) have shown that the Quilitage anticline has been active over the last $\sim 5 \mathrm{Ma}$. The growth of the fold must have impacted the sedimentary record and accumulation rates by either reducing the accommodation space above the growing structure or increasing the accommodation space behind the structure (through trapping of sediments in the piggy back basin). This effect can be corrected according to a fold growth model ([Charreau et al., 2009] and [Daëron et al., 2007]). In the present study we were not able to model this effect due to the complicated structure of the Quilitak antlicline.

\section{The Xiyu conglomerates: a prograding diachronous gravel wedge}

The Yaha section clearly shows clearly that the lithological contact between Xiyu conglomerates and their underlying sandstones observed on the southern and northern flanks of the Quilitage syncline, just $4.7 \mathrm{~km}$ apart (Fig. 4), lies at different stratigraphic depths. In addition, their estimated depositional ages are diachronous by $4.2 \mathrm{Ma}$ from one limb to the other (Fig. 4c and d). These features show that the Xiyu conglomerates grade laterally, away from the mountain front (Fig. 3 and Fig. 4). A similar pattern is observed along the Boguzihe section, in the western part of the southern Tianshan (Chen et al., 2002), where the base of the Xiyu conglomerates can be observed at two locations across the same Atushi-Talanghe anticline, with depositional ages estimated at 2.8 and $1.9 \mathrm{Ma}$ in less than $\sim 5 \mathrm{~km}$ apart. An analysis of a seismic line running across the Yakeng and Dushanzi anticlines shows important changes in seismic character (Fig. $8 \mathrm{a}$ and b) that may be interpreted as due to a sedimentological facies change from the homolithic Xiyu conglomerates to the underlying heterolithic and finer grained Neogene deposits mainly composed of sandstones (He et al., 2005). Geometry of contacts between these two lithologies further implies a depositional diachronism and younger age toward the basin.

In the southern Tianshan, across the foreland of the Kashi basin, in the western Tarim basin, several basal ages of the Xiyu conglomerates were magnetostratigraphically dated from 15.5 up to $0.7 \mathrm{Ma}$ (Heermance et al., 2007). In the northern Tianshan piedmont, at the Jingou $\mathrm{He}$ 
section, the limit between the Dushanzi and the Xiyu conglomerates was dated at $\sim 7.6 \mathrm{Ma}$ (Charreau et al., 2009), while at the Kuitun section $\sim 20 \mathrm{~km}$ to the north (basinward), the base of the Xiyu conglomerates were dated at $4.8 \mathrm{Ma}$ and $4.2 \mathrm{Ma}$, respectively (Charreau et al., 2005) (Fig. 8c). In the Chu basin in the northern Tianshan, the Sharpyldak formation, which is analogous to the Xiyu Formation, was magnetostratigraphically dated at $3 \mathrm{Ma}$ (Bullen et al., 2001).

This growing database shows that the deposition of the Xiyu Formation, and probably all similar alluvial fan deposits around the Tianshan, is highly diachronous at both local and regional scales. Fig. 9a shows the initial depositional age of the Xiyu conglomerates at various locations around the Tianshan as a function of the present distance from the range front. Because the range front topography is hard to define everywhere, the distance was estimated using the location of the tectonic contact between the Paleozoic and Mesozoic units as a reference. This plot shows a clear trend with decreasing ages from the mountain range toward the basin (Fig. 9a).

All these observations suggest that the Xiyu conglomerates are a time-transgressive alluvial gravel wedge unit that has prograded over the foreland as it was incorporated into the orogenic wedge (Fig. 10). The diachronous character of the Xiyu Formation in the Kashi area could reflect the effect of individual structures uplifting and causing reworking of sediments, and hence facilitating its basinward progradation (Heermance et al., 2007). However, in central Tianshan, no clear relationship exists between the depositional ages of the conglomerates and the activation of individual structures. Moreover, the predominance of clasts in the conglomerate that were derived from the high range suggests minor reworking of sediments due to emerging structures in the piedmont.

While the conglomerates prograded over the foreland, deformation propagated toward the basin as well ([Charreau et al., 2008a], [Daëron et al., 2007] and [Hubert-Ferrari et al., 2007]). Therefore, the Xiyu Formation may unconformably overlie previously deformed units in some places while in other places it lies conformably over underlying deposits, or exists as syn-kinematic growth strata (Charreau et al., 2008a). Thus, the stratigraphic relationship between the conglomerates and the underlying finer grained fluviatile units cannot be used as a criterion to define the base of the Xiyu Formation.

\section{Tectonic implications: a record of underthrusting rate?}

The nature of the Xiyu Formation as a prograding gravel wedge can be used to make tectonic inferences. First, the diachronism of the Xiyu conglomerates implies that they are not related to any particular episode of thrusting and uplift in and around the Tianshan or the Tibetan Plateau in the Plio-Pleistocene, as previously thought ([Burchfiel et al., 1999] and [Zheng et al., 2000]). For example, Zheng et al. (2000) dated the base of the Xiyu conglomerates at $\sim 3.5 \mathrm{Ma}$ in the Yecheng section in the western Kunlun piedmont, and inferred that the northern Tibetan plateau experienced rapid uplift at that time. This is likely incorrect, since the Xiyu Formation is most probably also transgressive at front of the western Kunlun. This particular depositional age of the conglomerates in Yecheng is probably only valid there and has no particular significance at regional-scale. However, because of the time-transgressive facies migration, the oldest settlement of this facies might be meaningful with regard to the age of reactivation of the range (Brozovic and Burbank, 2000). The oldest Xiyu conglomerates were dated at $\sim 15.5 \mathrm{Ma}$ in the Kashi piedmont (Heermance et al., 2007) 
suggesting that at this time the topography of the range had been sufficiently rejuvenated for erosion processes to lay down gravels along the piedmonts. This timing is consistent with the observation that the sediment accumulation rate accelerated at about that time, as seen in several sections around the range ([Charreau et al., 2009] and [Heermance et al., 2007]), and with thermochronological studies which suggest that exhumation in the range started earlier, possibly around $\sim 25 \mathrm{Ma}$ ([Dumitru et al., 2001], [Hendrix et al., 1994] and [Sobel et al., 2006]).

The plot in Fig. 9a shows a trend with the older Xiyu-type conglomerates lying closer to the mountain front. As this plot disregards potential deformation of the foreland, the $\sim 2 \mathrm{~mm} / \mathrm{yr}$ rate provides a minimum estimate of progradation of the conglomerates shed by the Tianshan range. To better quantify the progradation history of the conglomerate wedge, the present distances from the mountain front would need to be corrected for the amount of tectonic transport that may have taken place at each location posterior to deposition (as illustrated in the inset of Fig. 10). The distance of the transition from deposition of Xiyu-like conglomerates to finer grained fluviatile sediments depends primarily on two factors: (1) the transport capacity of the drainage system, and hence on topography and climate, and (2) the rate at which the foreland is moving toward the mountain front (Simoes and Avouac, 2006). So, the progradation rate within a particular section, $V_{\mathrm{pr}}$, measures the rate at which the study area has moved toward the range due to underthrusting ( $\mathrm{V}_{1}$ in Fig. 10), added to a general term that accounts for changes in topography and climate:

\section{$\underline{V_{\mathrm{pr}}}=V_{1}+f$ (topography,climate)}

The total shortening rate across the range is the sum of all shortening across individual faults $\left(V_{i}\right)$ and would be the underthrusting rate $V_{1}$ plus the overthrusting rate $\left(V_{2}\right.$ in Fig. 10; i.e., the rate at which rocks within the range are advected with respect to the steady-state topography):

$$
\sum V_{i}=V_{1}+V_{2}
$$

Both $V_{1}$ and $V_{2}$ have the same reference, which is the limit between the foreland and the basin (Fig. 10), but $V_{1}$ is positive from the basin toward the range while $V_{2}$ is negative. When erosion rates are low as in central Asia, $V_{2}$ represents only a small part of the thrusting rate across the range and can be neglected (Avouac, 2003). With measured shortening rates across individual faults, one can estimate $V_{1}$ and consequently constrain the influence of climate and topography. Thanks to several recent studies, long-term shortening rates are known in both Tianshan piedmonts.

Based on detailed constraints of the structure and age control, we restored the Yaha section. This yields a horizontal minimum distance of $\sim 4700 \mathrm{~m}$ between two points at the base of the Xiyu from the north and south limbs of the fold (Fig. 4c), which leads to a progradation rate of $\sim 1.2 \mathrm{~mm} / \mathrm{yr}$. Over that same period, shortening across the Yakeng and Quilitage anticlines (both located south of the Yaha section, Fig. 1) absorbed $\sim 0.6 \mathrm{~mm} / \mathrm{yr}$ and $\sim 0.2 \mathrm{~mm} / \mathrm{yr}$ from $\sim 5.5 \mathrm{Ma}$ to $0.2-0.3 \mathrm{Ma}$, respectively (Hubert-Ferrari et al., 2007). This adds $\sim 0.8 \mathrm{~mm} / \mathrm{yr}$ to $1.2 \mathrm{~mm} / \mathrm{yr}$, making it comparable to the progradation rate of $2.0 \mathrm{~mm} / \mathrm{yr}$. Hubert-Ferrari et al (2007) also found evidence for an increase of shortening rate across the two anticlines by a factor of 5 to 10 over the last $0.2-0.3 \mathrm{Myr}$. Yet, from the Quilitage anticline, the present position of the Xiyu-like conglomerates is about $\sim 20 \mathrm{~km}$ to the south, which implies a recent 
and strong increase in progradation rate. This might indicate short timescale fluctuations of shortening rates and/or climate that could not be identified by our analysis.

In the northern Tianshan, the basal age of Xiyu conglomerates has been dated at $2.5 \mathrm{Ma}$, $\sim 4.8 \mathrm{Ma}$, and $\sim 7.6 \mathrm{Ma}$ along the Anjihai (Zhou et al., 2000), Kuitun (Charreau et al., 2005) and Jingou He (Charreau et al., 2009) sections, respectively. It is possible to estimate the paleodistances of these points with respect to a common reference line in the foreland (here line that parallels the mean strike of piedmont's structures and fixed at latitude around $44^{\circ} 30^{\prime} \mathrm{N}$, see Fig. $3 \mathrm{~b}$ ) to restore the sections. The current distances were corrected assuming $\sim 1.2 \mathrm{~km}$ (Daëron et al., 2007) and $\sim 4 \mathrm{~km}$ ([Avouac et al., 1993], [Burchfiel et al., 1999] and [Molnar et al., 1994]) of shortening across the Dushanzi anticline along the Anjihai and Kuitun sections, respectively, and $\sim 10 \mathrm{~km}$ across the Huerguosi anticline (Charreau et al., 2008a). When plot on an age against distance diagram (Fig. 9b) those three restored paleodistances align well with the distance of Holocene fans in the area (Fig. 9b). We thus infer an average progradation rate of the Xiyu Formation over the Junggar basin of $\sim 3.9 \mathrm{~mm} / \mathrm{yr}$ over the last $10 \mathrm{Myr}$ (Fig. 9b). As the Kuitun section does not lie directly downstream of the JingouHe section, and because it is based on only four data points, this estimate should be taken with caution. For comparison the shortening rate across the Huerguosi and Anjihai anticlines (Fig. 1) is estimated at a minimum of $\sim 1.5 \mathrm{~mm} / \mathrm{yr}$ over the last $4 \mathrm{Myr}$, and a minimum of $\sim 1.1 \mathrm{~mm} / \mathrm{yr}$ from 4 to $\sim 10 \mathrm{Ma}$ (Charreau et al., 2008a). However, some fraction of the shortening across the piedmont is missing since it ignores shortening across the Qigu anticline and across a fault-tip fold in the footwall of the Huerguosi thrust fault (Charreau et al., 2008a). It seems therefore reasonable to assume that, here too, the progradation rates of the Xiyu Formation is comparable to the shortening rates.

For comparison in the Kashi area, restoring distance from shortening, Heermance et al. (2007) came to somewhat larger progradation rates of $10-11 \mathrm{~mm} / \mathrm{yr}$ for the same time period. A progradation rate larger in the Kashi area than in the Yaha section area is consistent with the westward increase of the shortening rate across the range ([Avouac et al., 1993] and [Reigber et al., 2001]).

These observations suggest that the progradation rate of the Xiyu Formation is primarily controlled by tectonics reflecting the rate of underthrusting of the foreland beneath the mountain front (Fig. 10). Note that, if so, the progradation rates observed north and south of the range should not add to the total shortening rate across the range since ovethrusting rates are not estimated and since there is also concomitant intermountain shortening, in particular within the Bayanbulak basin (Fig. 1). In any case, this study shows that the underthrusting rate at mountain fronts (the rate at which the basement of the foreland basin is thrust under the range) might be inferred from sedimentary facies migration provided that the effects of climate and eventual changes of the topography and sedimentary systems can be neglected or known independently.

\section{Climatic implications}

(Zhang et al., 2001) and (Molnar, 2004) analysed the sedimentary archive of several large basins around the world, including Junggar and Tarim. They observed a systematic and rapid increase in sediment shed to the basins at $\sim 4-2 \mathrm{Ma}$, around the Plio-Pleistocene transition. They linked this increase to the onset of glaciation that may have enhanced erosion rates and consequently impacted mountain building. In the case of central Asia, much of the data supporting this hypothesis are derived from 1D local accumulation rates or from the work of 
Métivier and Gaudemer (1997), who reconstructed regional sediment accumulation budgets based on 1D drilling logs. However, Métivier and Gaudemer (1997) concluded that a gradual, not sharp or punctual, increase in accumulation rates occurred since the early Miocene. Moreover, their sediment flux estimates must be handled with caution as their reconstruction is based on lithostratigraphic correlations that are probably biased by poorly constrained depositional ages. The inference of an increase in the sediment flux (Métivier and Gaudemer, 1997) and local accumulation rates (Zhang et al., 2001) at 4-2 Ma is, for example, linked to the strong assumption that the widespread Xiyu conglomerates were everywhere PlioPleistocene in age, which, as shown above, is no longer valid. Moreover, some magnetostratigraphic studies carried out around the Tianshan have revealed constant accumulation rates for the last 10-11 Ma ([Charreau et al., 2009], [Charreau et al., 2005] and [Charreau et al., 2006]). The same is true for the Neogene basins, of marginal seas along the Himalayan range front, where no major timing-dependant increase of the sediment supply was found in the depositional history (Clift, 2006) during this time period.

On the other hand, the estimates of (Clift, 2006) may not represent the total material eroded from the Himalayas since a significant part of the sediments could have been trapped in the Himalayan foreland (i.e. Siwaliks), and, more importantly, it ignores the Bay of Bengal. Moreover, accumulation rates derived from magnetostratigraphic studies are often carried out in syn-tectonic sediments across active folds, and must therefore be corrected for the effect of fold growth (Charreau et al., 2008a). Finally, some studies show evidence for local increases in accumulation rate during the Plio-Pleistocene. For example, magnetostratigraphy in the JingouHe section suggest that the sedimentation rate in the piggyback basin increased abruptly from $\sim 0.4$ to $\sim 0.7 \mathrm{~mm} / \mathrm{yr}$ at ca. $4 \mathrm{Ma}$ (Charreau et al., 2008a). Magnetostratigraphic dating of the Kashi town sections in the Kashi foreland, in the western Tarim basin, also shows a significant accumulation rate acceleration ca. $4 \mathrm{Ma}$ (Heermance et al., 2007). However it might be questionable that the 1D accumulation profiles derived from the Jingou He and Kashi sections can be extrapolated to sediment supply over the whole of central Asia given the possible influence of local tectonic factors. Therefore, one can naturally conclude that no strong evidence exists, yet, for a Quaternary sediment flux acceleration in the Tarim and Junggar basins, or for a relationship between the Xiyu conglomerate and the onset of Quaternary glaciation in central Asia.

\section{Conclusions}

The Xiyu Formation is a thick conglomeratic unit that has inspired various inferences with regards to the timing of mountain building and the effect of climate change in central Asia. The available data from magnetostratigraphic, sedimentological and structural studies of this formation reveal that it constitutes a prograding gravel wedge with diachronous ages ranging between $\sim 15.5$ and $\sim 0.7 \mathrm{Ma}$. The Xiyu Formation cannot be considered as a chronostratigraphic unit marker throughout the continental basins of central Asia. We suggest that the progradation rate of the Xiyu Formation primarily reflects the rate at which the foreland is thrust under the mountain range but that it must also reflect the evolution of topography and climate.

Given the depositional diachronism of the Xiyu conglomerates, no evidence exists for a regional accumulation rate acceleration at the Plio-Pleistocene transition to support the idea that a change in regional climate occurred as reflected in the onset of Quaternary glaciation, or of a sudden increase in topographic relief in central Asia. The impact of the PlioPleistocene climatic transition on mountain building and mass transfer remains, therefore, an 
open debate in central Asia. We suggest that the Tarim and Junggar intracontinental basins may represent remarkable test cases to address this key issue in the future because sediment flux could potentially be estimated in this closed system. In this regard, more chronological data and good constraints on basin geometry are strongly needed to reconstruct accurate sediment volumes.

\section{Acknowledgments}

This study was financed by the French ECLIPSE program, the Chinese project kzcx3-sw-147 and 973 No 2005CB422101, PRA (T05-02/T06-04), the French ANR (ANR-05-BLAN-014301 ) and the Gordon Betty Moore Foundation. We present our thanks to Dr. S. Peng and K. Chen for their supports to magnetostratigraphic sampling and to M. Laumonier and E. de Oliveira for their help in the laboratory. This is Caltech Tectonics Observatory contribution 123.

\section{References}

Avouac, 2003 J.-P. Avouac, Mountain building, erosion, and the seismic cycle in the Nepal Himalaya, Adv. Geophys. 46 (2003), pp. 1-79.

Avouac and Burov, 1996 J.-P. Avouac and E.B. Burov, Erosion as a driving mechanism of intracontinental mountain growth, J. Geophys. Res. 101 (1996), p. 17747.

Avouac et al., 1993 J.-P. Avouac, P. Tapponnier, P. Bai, M. You and G.A. Wang, Active Thrusting and folding along the northern Tien Shan and late Cenozoic rotation of the Tarim relative to Dzungaria and Kazakhstan, J. Geophys. Res. 98 (1993), pp. 11.791-11.808.

Batt and Braun, 1997 G.E. Batt and J. Braun, On the thermomechanical evolution of compressional orogens, Geophys. J. Int. 128 (1997), pp. 364-382

Beaumont et al., 1994 C. Beaumont, P. Fullsack and J. Hamilton, Styles of crustal deformation in compressional orogens caused by subduction of the underlying lithosphere, Tectonophysics 232 (1994), pp. 119-132.

Beaumont et al., 1988 C. Beaumont, G. Quinlan and J. Hamilton, Orogeny and stratigraphy: numerical models of the Paleozoic in the eastern interior of the North America, Tectonics 7 (1988), pp. 389-416.

Blair and McPherson, 1994 T.C. Blair and J.G. McPherson, Alluvial fans and their natural distinction from rivers based on morphology, hydrolic processes, sedimentary processes, and facies assemblages, J. Sediment. Res. A64 (1994), pp. 450-489.

Brozovic and Burbank, 2000 N. Brozovic and D.W. Burbank, Dynamic fluvial systems and gravel progradation in the Himalayan foreland, Geol. Soc. Am. Bull. 112 (2000), pp. 394-412.

Bullen et al., 2003 M.E. Bullen, D.W. Burbank and J.I. Garver, Building the northern Tien Shan: integrated thermal, structural, and topographic constraints, J. Geol. 111 (2003), pp. 149-165. 
Bullen et al., 2001 M.E. Bullen, D.W. Burbank, J.I. Garver and K.Y. Abdrakhmatov, Late Cenozoic tectonic evolution of the northwestern Tien Shan: new age estimates for the initiation of mountain building, Bull. Geol. Soc. Am. 113 (2001), pp. 1544-1559.

Burbank, 1992 D.W. Burbank, Causes of recent Himalaya uplift deduced from depositional patterns in the Ganges basin, Nature 257 (1992), pp. 680-683.

Burchfiel et al., 1999 B.C. Burchfiel, E.T. Brown, Q. Deng, J. Li, X. Feng, P. Molnar, J. Shi, $\mathrm{Z}$. Wu and $\mathrm{H}$. You, Crustal shortening on the margins of the Tian Shan: Xinjiang, China, Int. Geol. Rev. 41 (1999), pp. 663-700.

Bureau of the Geological and the Mineral Resources of the Xinjiang Uygur Autonomous Region, 1985 Bureau of the Geological and the Mineral Resources of the Xinjiang Uygur Autonomous Region, 1985, Geological map of the Xinjiang Uygur Autonomous Region, China.

Burtman, 1975 V.S. Burtman, Structural geology of the Variscan Tian Shan, USSR, Am. J. Sci. 275-A (1975), pp. 157-186.

Charreau et al., 2008a J. Charreau, J.-P. Avouac, Y. Chen, S. Dominguez and S. Gilder, Miocene to present kinematics of fault-bend folding across the Huerguosi anticline, northern Tianshan (China), derived from structural, seismic, and magnetostratigraphic data, Geology (2008), pp. 871-874.

Charreau et al., 2008b Charreau, J., Chen, Y., Gilder, S., Barrier, L. 2008b. Comment on "Magnetostratigraphic study of the Kuche Depression, Tarim Basin, and Cenozoic uplift of the Tian Shan Range, Western China" Baochun Huang, John D.A. Piper, Shoutao Peng, Tao Liu, Zhong Li, Qingchen Wang, Rixiang Zhu [Earth Planet. Sci. Lett., 2006, doi:10.1016/j.epsl.2006.09.020]: Earth Planet. Sci. Lett. v. 268, p.325-329.

Charreau et al., 2009 J. Charreau, Y. Chen, S. Gilder, L. Barrier, S. Dominguez, R. Augier, S. Sen, J.-P. Avouac, A. Gallaud, F. Graveleau and Y. Li, Neogene uplift pulses of the Tianshan mountains observed in the magnetic record of the Jingou River section (Northwest China), Tectonics 28 (2009) doi:10.1029/2007TC002137.

Charreau et al., 2005 J. Charreau, Y. Chen, S. Gilder, S. Dominguez, J.-P. Avouac, S. Sevket, D. Sun, Y. Li and W.-M. Wang, Magnetostratigraphy and rock magnetism of the Neogene Kuitun He section (northwest China): implications for Late Cenozoic uplift of the Tianshan mountains, Earth Planet. Sci. Lett. 230 (2005), pp. 177-192

Charreau et al., 2006 J. Charreau, S. Gilder, Y. Chen, S. Dominguez, J.-P. Avouac, S. Sevket, M. Jolivet, Y. Li and W. Wang, Magnetostratigraphy of the Yaha section, Tarim Basin (China): $11 \mathrm{Ma}$ acceleration in erosion and uplift of the Tianshan Mountains, Geology 34 (2006), pp. 181-184.

Charvet et al., 2007 J. Charvet, L.S. Shu and S. Laurent-Charvet, Paleozoic structural and geodynamic evolution of eastern Tianshan (NW China): welding of the Tarim and Junggar plates, Episodes 30 (2007), pp. 162-186. 
Chen et al., 1994 H. Chen, X.L. Lin, K.N. Guan and J.M. Xu, Early Pleistocene deposits and its lower boundary (Q/N) in Tian Shan MT: Xinjiang Region, Quat. Sci. 1 (1994), pp. 38-47.

Chen et al., 2002 J. Chen, D.W. Burbank, K.M. Scharer, E. Sobel, J. Yin, C. Rubin and R. Zhao, Magnetochronology of the Upper Cenozoic strata in the Southwestern Chinese Tian Shan: rates of Pleistocene folding and thrusting, Earth Planet. Sci. Lett. 195 (2002), pp. 113 130.

Clift, 2006 P.D. Clift, Controls on the erosion of Cenozoic Asia and the flux of clastic sediment to the ocean, Earth Planet. Sci. Lett. 241 (2006), pp. 571-580.

Cobbold et al., 1993 P. Cobbold, P. Davis, D. Gapais, E.A. Rosselllo, I.S. Sadybakasov, J.-C. Thomas, J.J. Tondji Bijo and M. De Urreiztieta, Sedimentary and basin and crustal thickening, Sediment. Geol. 86 (1993), pp. 77-89.

Daëron et al., 2007 M. Daëron, J.-P. Avouac, J. Charreau and S. Dominguez, Modeling the shortening history of a fault-tip fold using structural and geomorphic records of deformation, J. Geophys. Res. 12 (2007) doi:10.1029/2006JB004460.

Dumitru et al., 2001 T.A. Dumitru, D. Zhou, E.Z. Chang, S.A. Graham, M.S. Hendrix, E.R. Sobel and A.R. Caroll, Uplift, exhumation, and deformation in the Chinese Tian Shan. In: M.S. Hendrix and G.A. Davis, Editors, Paleozoic and Mesozoic tectonic evolution of central Asia: from continental assembly to intracontinental deformation vol 194, Geological Society of America Memoir, Boulder, Colorado (2001), pp. 71-99.

Feng and Dai, 2004 X.J. Feng and W.Q. Dai, Lateral migration of fault activity in Weihe basin, Acta Seismol. Sin. 17 (2004), pp. 190-199.

Gaboardi et al., 2005 M. Gaboardi, T. Deng and Y. Wang, Middle Pleistocene climate and habitat change at Zhoukoudian, China, from the carbon and oxygen isotopic record from herbivore tooth enamel, Quat. Res. 63 (2005), pp. 329-338.

Gao et al., 1998 J. Gao, M. Li, X. Xiao, Y. Tang and G. He, Paleozoic tectonic evolution of the Tianshan Orogen, northwestern China, Tectonophysics 287 (1998), pp. 213-231.

Gloppen and Steel, 1981 T.G. Gloppen and R.J. Steel, The deposits, internal structure and geometry in six alluvial fan-fan delta bodies (Devonian-Norway) — a study in the significance of bedding sequence in conglomerates, Spec. Publ. Soc. Econ. Paleontol. Mineral. 31 (1981), pp. 49-69

He et al., 2005 D. He, J. Suppe, Y. Geng, G. Shuwei, H. Shaoying, S. Xin, W. Xiaobo and Z. Chaojun, Guide book for field trip in south and north Tianshan foreland basin, Xinjiang Uygur Autonomous Region, China, International conference on theory and application of fault-related folding in foreland basins (2005), p. 77.

Heermance et al., 2007 R.V. Heermance, J. Chen, D.W. Burbank and C. Wang, Chronology and tectonic controls of Late Tertiary deposition in the southwestern Tian Shan foreland, NW China, Basin Res (2007) doi:10.1111/j.1365-2117.2007.00339.x. 
Hendrix et al., 1994 M.S. Hendrix, T.A. Dumitru and A.S. Graham, Late Oligocene-early Miocene unroofing in the Chinese Tian Shan: an early effect of the India-Asia collision, Geology 22 (1994), pp. 487-490.

Huang et al., 2006 B. Huang, J.D.A. Piper, S. Peng, T. Liu, Z. Li, Q. Wang and R. Zhu, Magnetostratigraphic study of the Kuche Depression: Tarim Basin, and Cenozoic uplift of the Tian Shan Range, Western China, Earth Planet. Sci. Lett. 251 (2006), pp. 346-364.

Hubert-Ferrari et al., 2007 A. Hubert-Ferrari, J. Suppe, R. Gonzalez-Mieres and X. Wang, Mechanism of active folding of the landscape (southern Tianshan, China), J. Geophys. Res. 112 (2007) doi:10.1029/2006JB004362.

Hubert-Ferrari et al., 2005 A. Hubert-Ferrari, J. Suppe, X. Wang and C. Jia, The Yakeng detachment fold, China. In: J.H. Shaw, C. Connors and J. Suppe, Editors, Seismic interpretation of contractional fault-related folds, American Association of Petroleum Geologists (2005), pp. 110-113.

Jamieson and Beaumont, 1988 R.A. Jamieson and C. Beaumont, Orogeny and metamorphism: a model for deformation and pressure-temperature-time paths with applications to the central and southern Appalachians, Tectonics 7 (1988), pp. 417-445.

Koons, 1987 P.O. Koons, Some thermal and mechanical consequences of rapid uplift: an example from the Southern Alps New Zealand, Earth Planet. Sci. Lett. 86 (1987), pp. 307319.

Lin et al., 2008 W. Lin, M. Faure, Y. Shi, Q. Wang and Z. Li, Palaeozoic tectonics of the south-western Chinese Tianshan: new insights from a structural study of the highpressure/low-temperature metamorphic belt, Int. J. Earth Sci (2008) doi:10.1007/s00531-008$0371-7$.

Liu et al., 1996 T. Liu, M. Ding and E. Derbyshire, Gravel deposits on the margins of the Qinghai-Xizang plateau, and their environmental significance, Palaeogeogr., Palaeoclimatol., Palaeoecol. 120 (1996), pp. 159-170.

Lourens et al., 2004 Lourens, L., Hilgen, F., Shackleton, N.J., Laskar, J., Wilson, D., 2004, The Neogene Period. In: J. G. O. Felix M. Gradstein, Alan G. Smith (Eds.), A Geological Time Scale: London, Cambridge.

Mack and Leeder, 1999 G.H. Mack and M.R. Leeder, Climatic and tectonic controls on alluvial fan and axial fluvial sedimentation in the Plio-Pleistocene Palomas half graben, southern Rio Grande Rift, J. Sediment. Res. 69 (1999), pp. 635-652.

McFadden and McEhlinny, 1990 P.L. McFadden and M.W. McEhlinny, Classification of the reversal test in paleomagnetism, Geophys. J. Int. 103 (1990), pp. 725-729.

Métivier and Gaudemer, 1997 F. Métivier and Y. Gaudemer, Mass transfer between eastern Tien Shan and adjacent basins (central Asia): constraints on regional tectonics, Geophys. J. Int. 128 (1997), pp. 1-17.

Miall, 1977 A.D. Miall, A review of the braided river depositional environment, Earth Sci. Rev. 13 (1977), pp. 1-62 
Miall, 1978 A.D. Miall, Facies types and vertical profile models in braided river deposits: a summary. In: A.D. Miall, Editor, Fluvial Sedimentology: Memoirs of the Canadian Society of Petroleum Geologists vol 5 (1978), pp. 597-604.

Molnar, 2004 P. Molnar, Late Cenozoic increase in accumulation rates of terrestrial sediment: how might climate change have affected erosion rates?, Annu. Rev. Earth Planet. Sci. 32 (2004), pp. 67-89.

Molnar et al., 1994 P. Molnar, E.T. Brown, B.C. Burchfiel, Q. Deng, X. Feng, J. Li, G.M. Raisbeck, J. Shi, Z. Wu, F. Yiou and H. You, Quaternary climate change and the formation of river terraces across growing anticlines on the north flank of the Tien Shan China, J. Geol. 102 (1994), pp. 583-602.

Molnar and England, 1990 P. Molnar and P. England, Late Cenozoic uplift of mountain ranges and global climate change: chicken or egg?, Nature 346 (1990), pp. 29-34.

Nemec and Postma, 1993 W. Nemec and G. Postma, Quaternary alluvial fans in the southwestern Crete: sedimentation processes and geomorphic evolution. In: M. Marzo and C. Puigdefábregas, Editors, Alluvial Sedimentation: International Association of Sedimentologists Special Publications vol 17 (1993), pp. 235-276.

Reigber et al., 2001 C. Reigber, G.W. Michel, R. Galas, D. Angermann, J. Klotz, J.Y. Chen, A. Papschev, R. Arslanov, V.E. Tzurkov and M.C. Ishanov, New space geodetic constraints on the distribution of deformation in the Central Asia, Earth Planet. Sci. Lett. 191 (2001), pp. $157-165$.

Schlunegger et al., 1997 F. Schlunegger, T.E. Jordan and E.M. Klaper, Controls of erosional denudation in the orogen on foreland basin evolution: the Oligocene central Swiss Molasse Basin as an example, Tectonics 16 (1997), pp. 823-840.

Simoes and Avouac, 2006 M. Simoes and J.P. Avouac, Investigating the kinematics of mountain building in Taiwan from the spatiotemporal evolution of the foreland basin and western foothills, J. Geophys. Res. B: Solid Earth 111 (2006), p. B10401 doi:10.1029/2005JB004209.

Simons et al., 1965 D.B. Simons, E.V. Richardson and C.F. Nordin Jr, Sedimentary structures generated by flow in alluvial channels. In: G.V. Middleton, Editor, Primary Sedimentary Structures and Their Hydrodynamic Interpretation: Special Publications of the Society of Economic Paleontologists and Mineralogists vol 12 (1965), pp. 34-52.

Sobel et al., 2006 E. Sobel, J. Chen and R.V. Heermance, Late Oligocene-Early Miocene initiation of shortening in the Southwestern Chinese Tian Shan: implications for Neogene shortening rate variations, Earth Planet. Sci. Lett. 247 (2006), pp. 70-81.

Sobel and Dumitru, 1997 E.R. Sobel and T.A. Dumitru, Thrusting and exhumation around the margins of the western Tarim basin during India-Asia collision, J. Geophys. Res. 102 (1997), pp. 5043-5063. 
Southard and Boguchwal, 1990 J.B. Southard and L.A. Boguchwal, Bed configurations in steady unidirectional water flows, part 1: synthesis of flume data, J. Sediment. Petrol. 60 (1990), pp. 658-679.

Sun et al., 2007 J. Sun, Q. Xu and B. Huang, Late Cenozoic magnetochronology and paleoenvironmental changes in the northern foreland basin of the Tian Shan Mountains, $J$. Geophys. Res. B: Solid Earth 112 (2007) doi:10.1029/2006JB004653.

Sun et al., 2004 J. Sun, R. Zhu and J. Bowler, Timing of the Tianshan Mountains uplift constrained by magnetostratigraphic analysis of molasse deposits, Earth Planet. Sci. Lett. 219 (2004), pp. 239-253.

Wan and Sandilands, 1995 A.R.H. Wan and M. Sandilands, Introduction to geological data analysis, Blackwell Sciences (1995) 446 p.

Wang et al., 2008 B. Wang, M. Faure, L. Shu, D. Cluzel, J. Charvet, K. De Jong and Y. Chen, Paleozoic tectonic evolution of the Yili Block, western Chinese Tianshan, Bulletin de la Société Géologique de France 179 (2008), pp. 483-490.

Whipple and Meade, 2006 K.X. Whipple and B.J. Meade, Orogen response to changes in climatic and tectonic forcing, Earth Planet. Sci. Lett. 243 (2006), pp. 218-228.

Windley et al., 1990 B.F. Windley, M.B. Allen, C. Zhang, Z.-Y. Zhao and G.R. Wang, Paleozoic accretion and Cenozoic deformation of the Chinese Tien Shan Range, central Asia, Geology 18 (1990), pp. 128-131

Zachos et al., 2001 J. Zachos, M. Pagani, L. Sloan, E. Thomas and K. Billups, Trends, rhythms and aberrations in global climate 65 Ma to Present, Science 292 (2001), pp. 686-693.

Zhang et al., 2001 P. Zhang, P. Molnar and W.R. Downs, Increased sedimentation rates and grain sizes 2-4 Myr ago due to the influence of climate change on erosion rates, Nature 410 (2001), pp. 891-897.

Zheng et al., 2000 H.B. Zheng, C.M. Powell, Z. An, J. Zhou and G. Dong, Pliocene uplift of the northern Tibetan Plateau, Geology 28 (2000), pp. 715-718.

Zhou et al., 2000 In: M. Zhou, L. Wen and S. Wang, Editors, Quaternary in Chinese Stratigraphy (in Chinese), Geology Publication House (2000) 117 p.

Zhu et al., 2004 R.X. Zhu, R. Potts, F. Xie, K.A. Hoffman, C.L. Deng, C.D. Shi, Y.X. Pan,

H.Q. Wang, R.P. Shi, Y.C. Wang, G.H. Shi and N.Q. Wu, New evidence on the earliest human presence at high northern latitudes in northeast Asia, Nature 431 (2004), pp. 559-561.

Zijderveld, 1967 J.D.A. Zijderveld, A.C. demagnetization of rocks: analysis of results. In: D.W. Collinson, K.M. Creer and S.K. Runcorn, Editors, Methods in Paleomagnetism (1967), pp. 254-286. 


\section{Figures}

a)

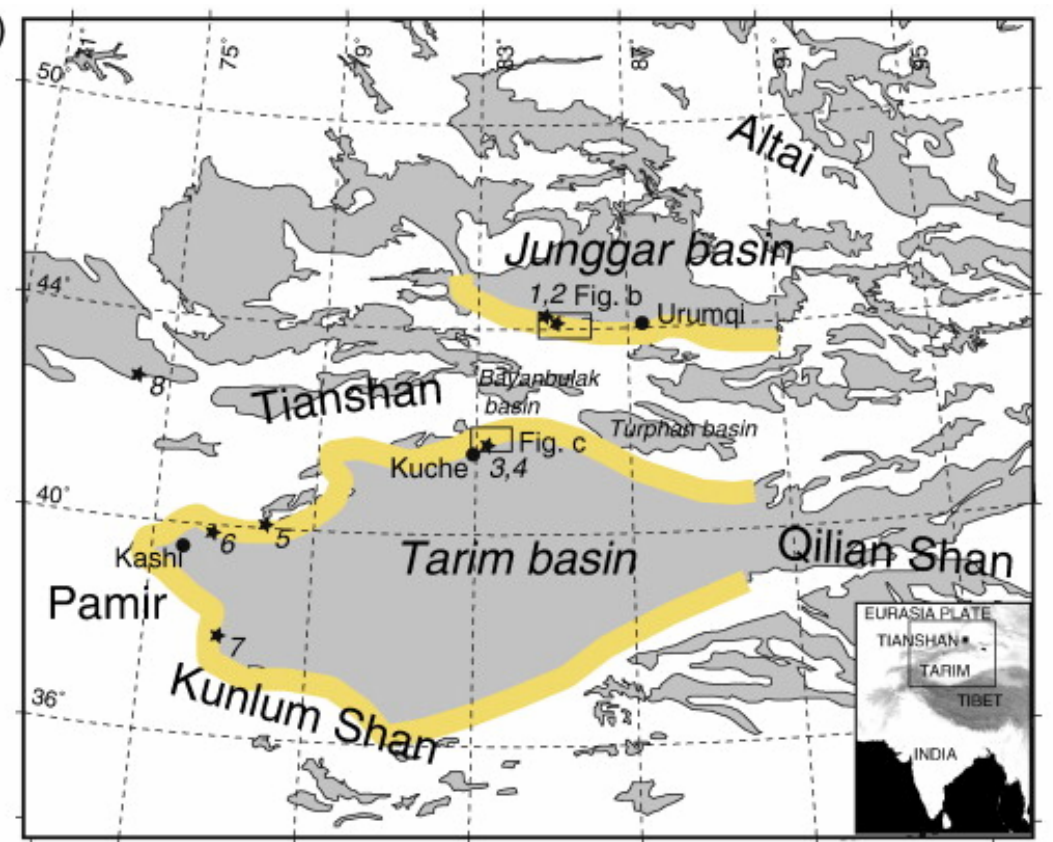

b)

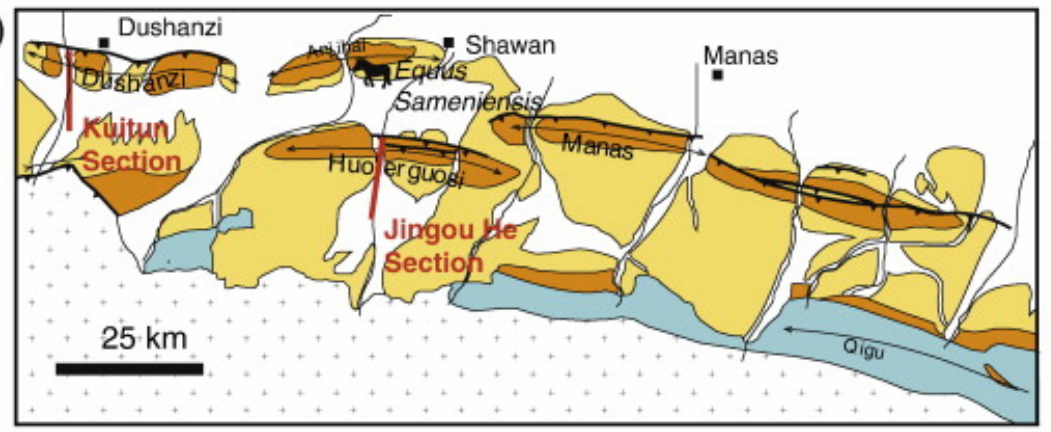

c)

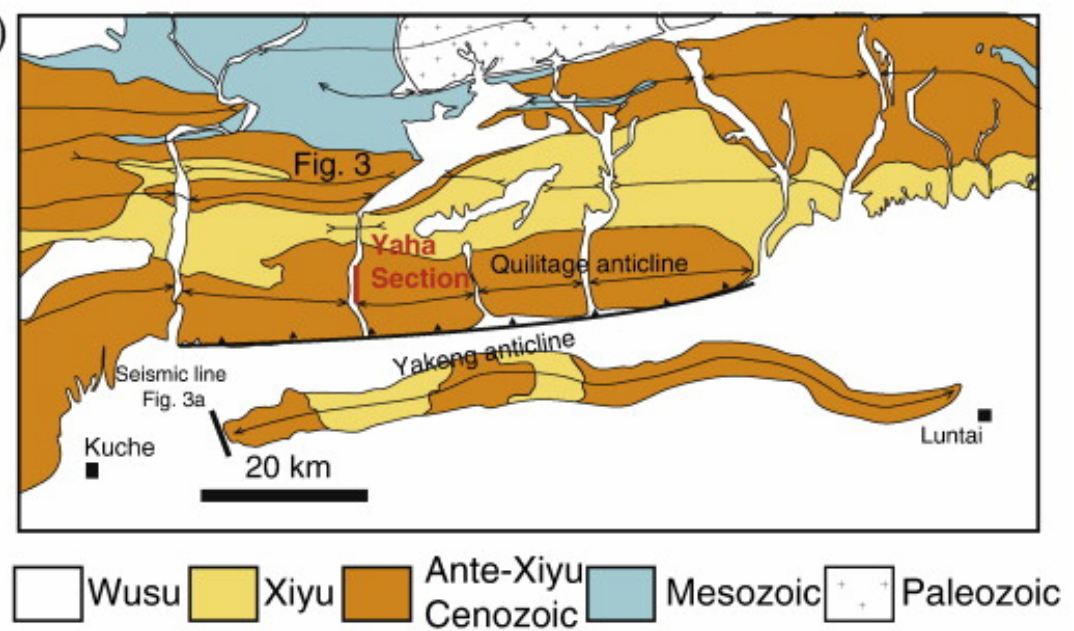

Fig. 1. (a) Map of central Asia with the repartition in grey of supposed Quaternary sediments and highlighted in yellow are the piedmont where the Xiyu Formation is identified. Black stars indicate locations of magnetostratigraphic studies that provide basal ages of the Xiyu Formation with (1) Charreau et al. (2009), (2) Charreau et al. (2005), (3) Charreau et al. (2009), (4) Huang et al. (2006), (5) Chen et al. (2002), (6) Heermance et al. (2007), (7) Zheng et al. (2000); (8) Bullen et al., 2001; (b) Geologic map of the northern Tianshan piedmont with location of the Jingou He (Charreau et al., 2009) and Kuitun sections (Charreau et al., 2005). Black horse indicates the location where fossil Equus Sameniensis has been found; (c) Geological map of the southern Kuche piedmont and location of the Yaha section (Charreau et al., 2006). 
a)

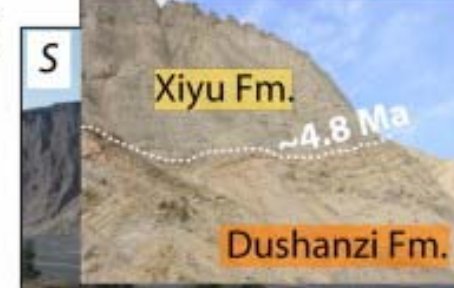

b)

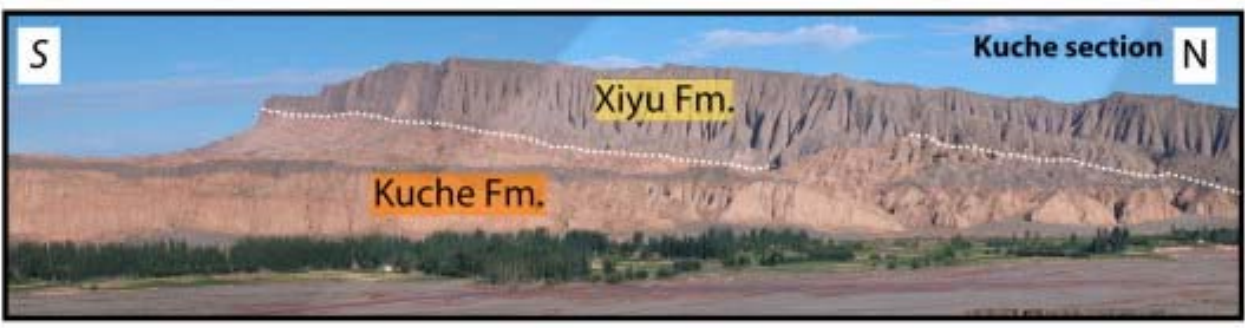

c)

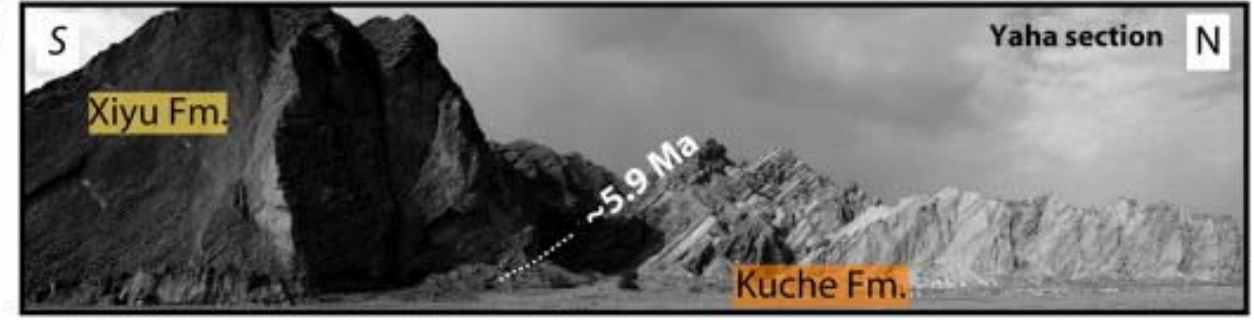

d)

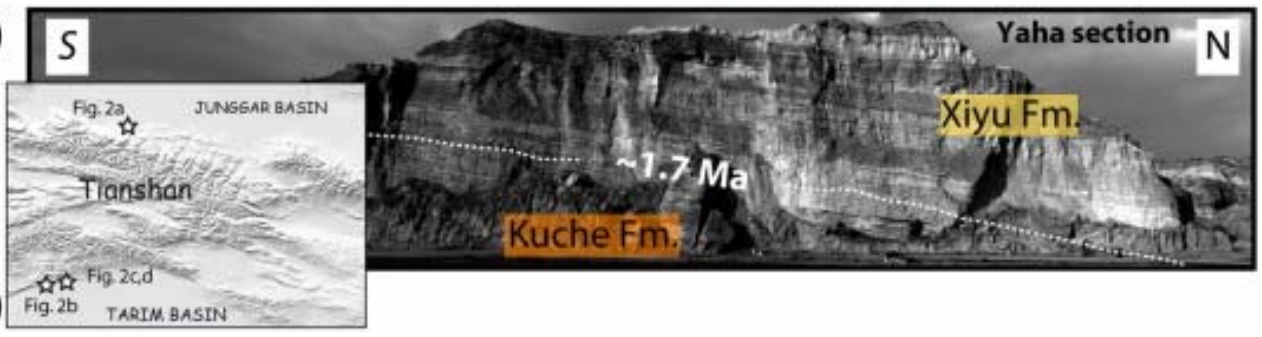

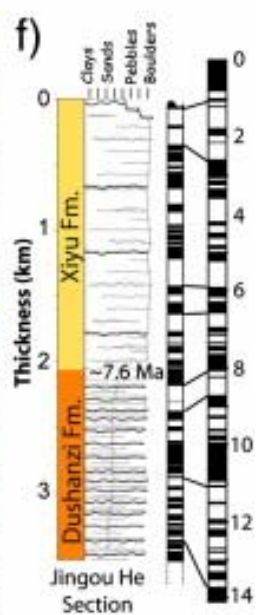

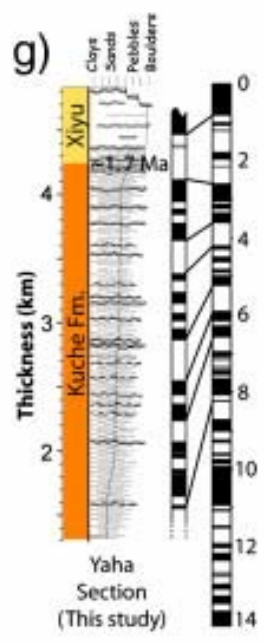

Fig. 2. (a) Panorama of the Xiyu/Dushanzi transition in the Kuitun section with enlargement of the transition on the left; (b) Panorama of the Xiyu/Kuche transition in the Kuche section located $\sim 20 \mathrm{~km}$ west of the Yaha section (see Fig. 1); (c) Panorama of the Xiyu/Kuche transition in the Yaha section north of the Quilitage syncline (see location in Fig. 4); (d) Photograph of the Xiyu/Kuche transition of the Yaha section in south of the Quilitage syncline (see location in Fig. 4) which shows lateral lithological variations as dark conglomeratic layers are thinner toward south and evolve laterally toward sandstone; (e) topographic map of the Tianshan showing location of photograph and panorama; (f) Synthetic stratigraphic log from the Jingou He section showing the characteristic lithology and facies of the Xiyu Formation; (g) Synthetic stratigraphic log from the Yaha section. 

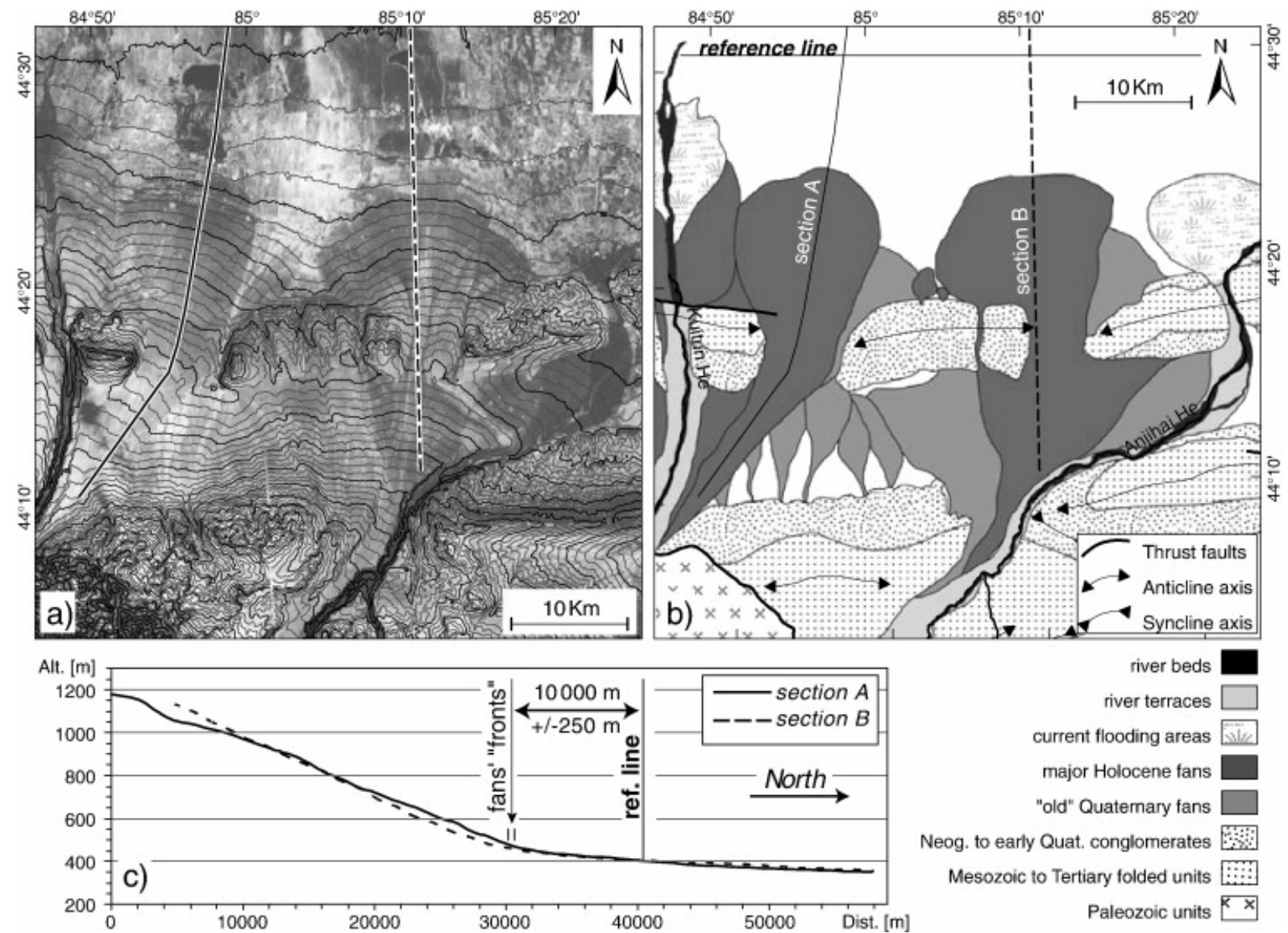

river beds

river terraces

current flooding areas

major Holocene fans

"old" Quaternary fans

Neog. to early Quat. conglomerates

Mesozoic to Tertiary folded units

Paleozoic units $x$

Fig. 3. (a) Contour interval of $25 \mathrm{~m}$ superimposed on a Landsat satellite image of the Kuitun/Jingou He area; (b) geomorphic interpretation of the studied area showing major recent alluvial fans (c) topographic profiles along sections A and B (see location in panel b) which show a strong break in slope used to place the limit of Xiyu-like fan deposits. 
a)

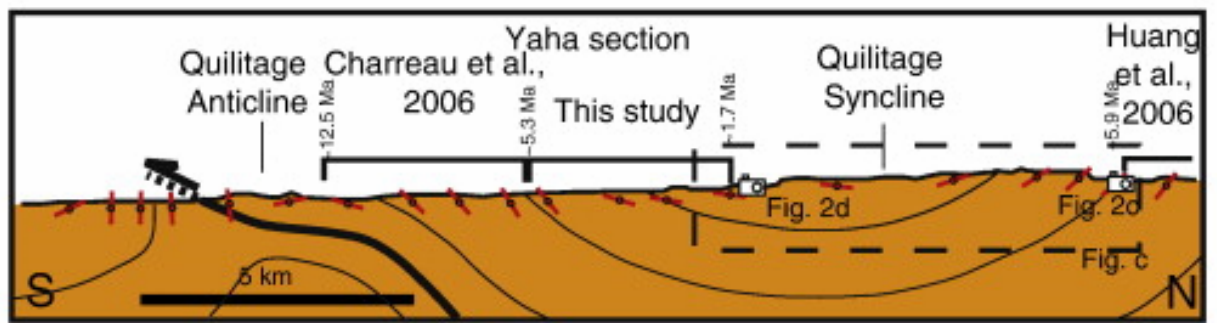

b)

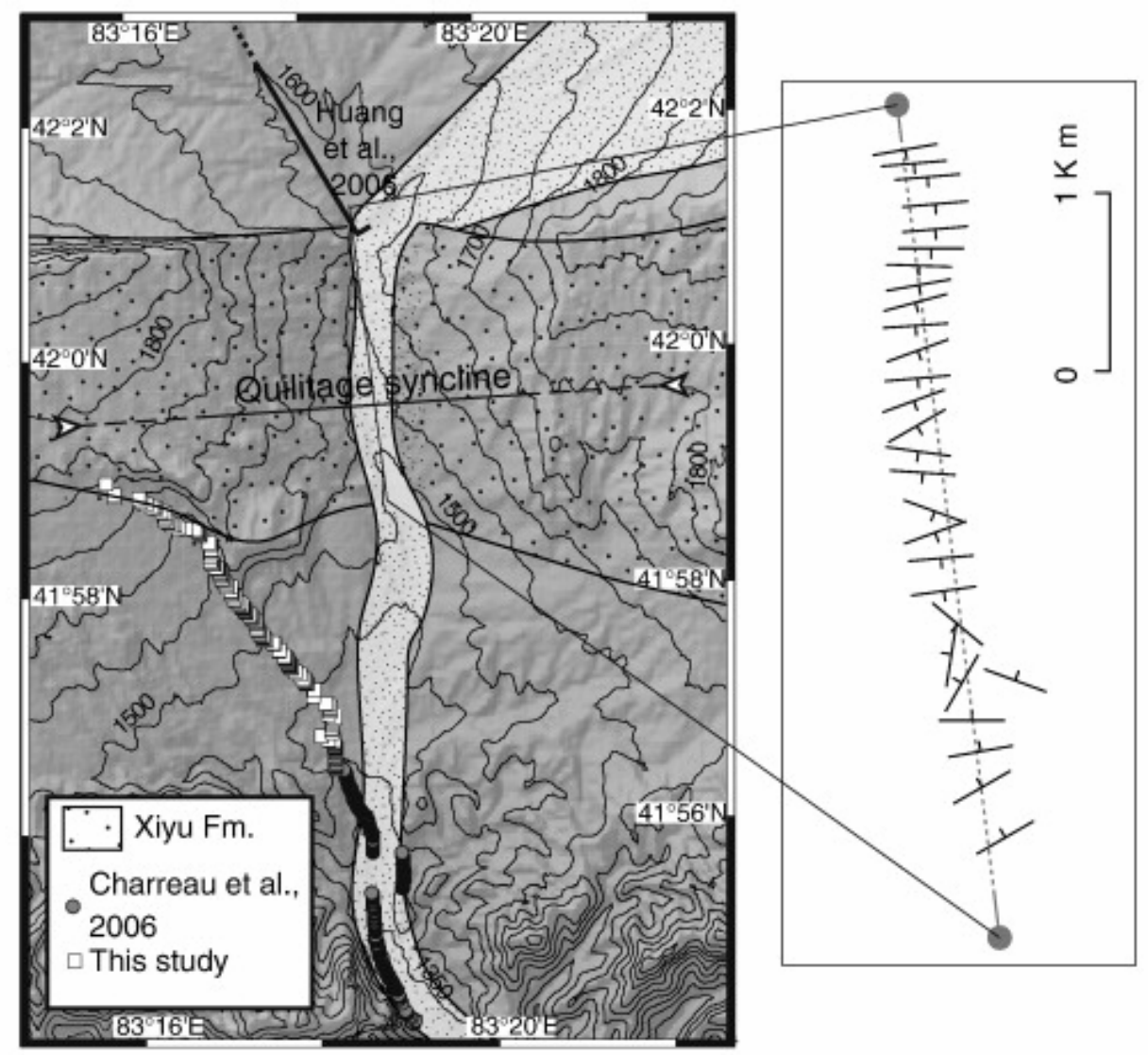

c) $\mathrm{S}$
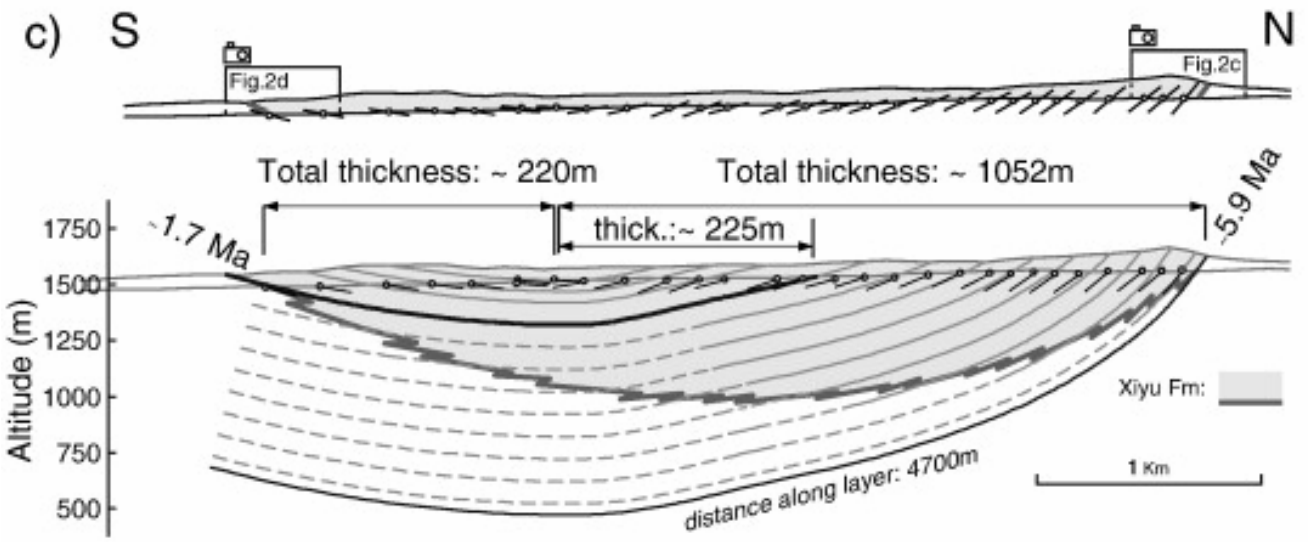

Fig. 4. (a) Simplified cross section of the Quilitage anticline and syncline with the locations of the different magnetostratigraphic studies which provide bound on the basal ages of the Xiyu Formation; (b) Topographic map of the Yaha river with location of the magnetostratigraphic sampling sites of Charreau et al. (2006) and this study; (c) Detailed balanced cross section of the Quilitage syncline with location of the 29 structural measurements and the exact position of the two lithological transitions between the Xiyu conglomerates and underlying Neogene Kuche Formation. 
a)

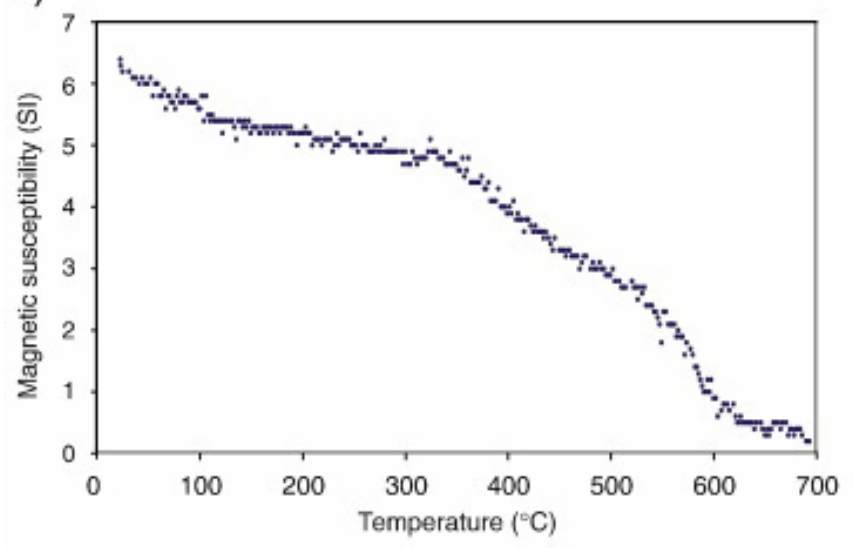

c)

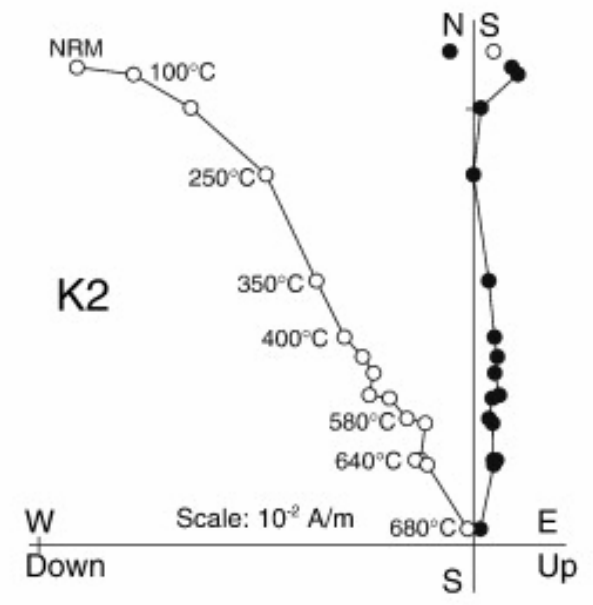

e)

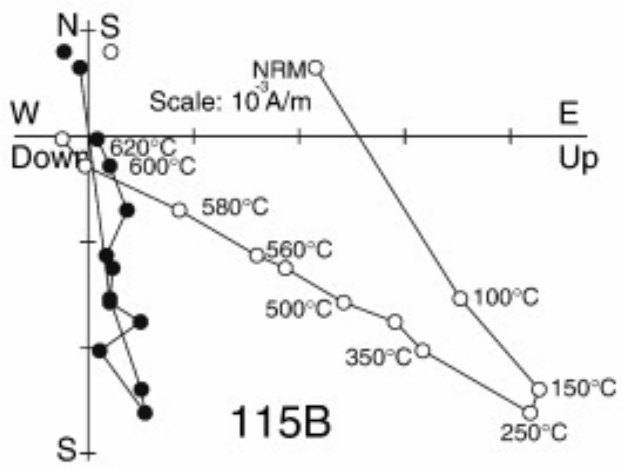

b)

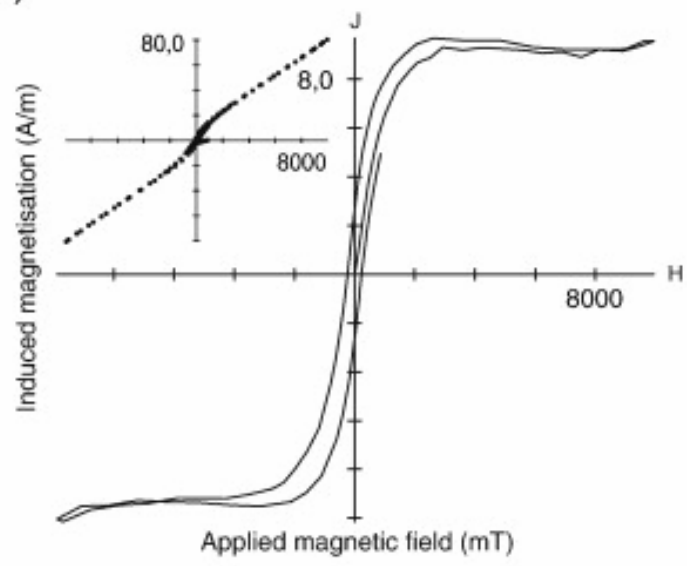

d)

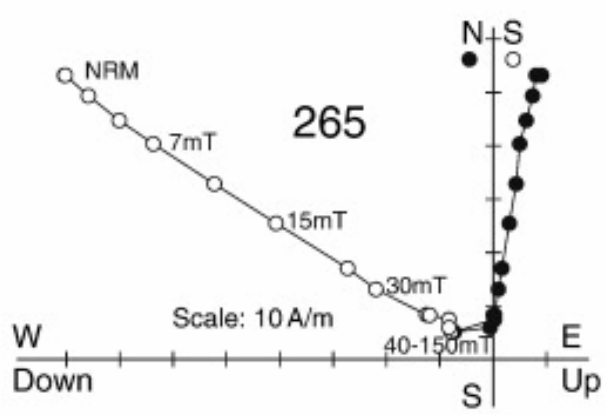

f)

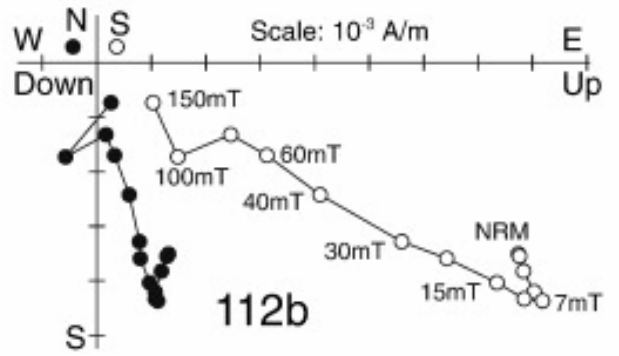

Fig. 5. (a) Curie point analyses and (b) Hysteris curves of representative samples; (c to f) Representative Zijderveld diagrams (Zijderveld, 1967) obtained from both thermal and alternating field (AF) demagnetization (in situ coordinates). 
(a)

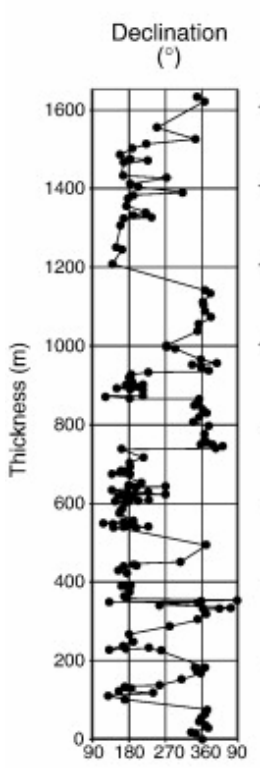

(b) Inclination

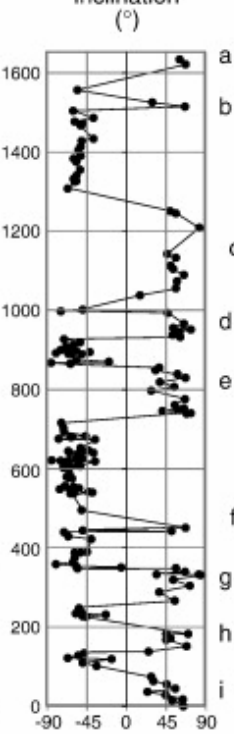

(c)

(d)

Geomagnetic

Polarity colunm time scale (Ma) Polarity colunm (e)
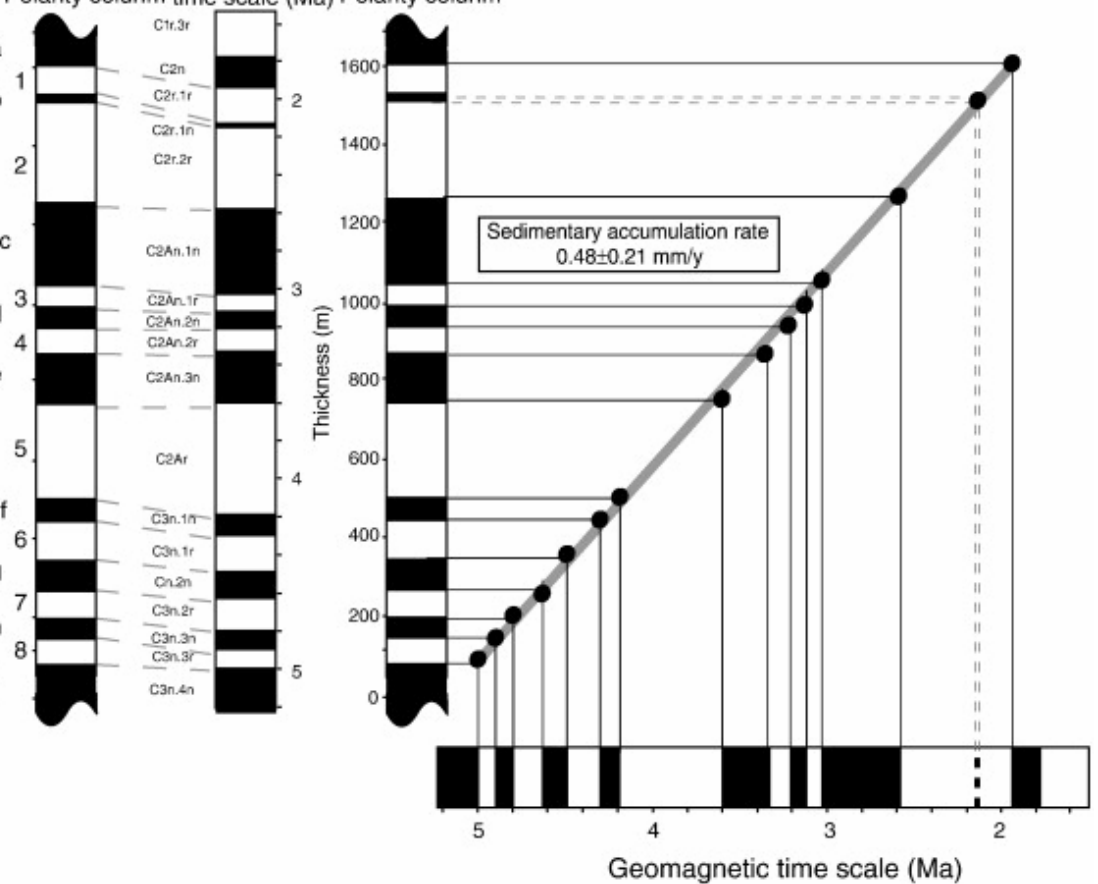

Fig. 6. Paleomagnetic declination (a) and inclination (b) obtained using principal component analysis; (c) Magnetostratigraphic column from this study; (d) Reference polarity time scale after Lourens et al. (2004); (e) Age versus depth plot of the upper Yaha section, using the data and correlation from $\mathrm{c}$ and $\mathrm{d}$. 


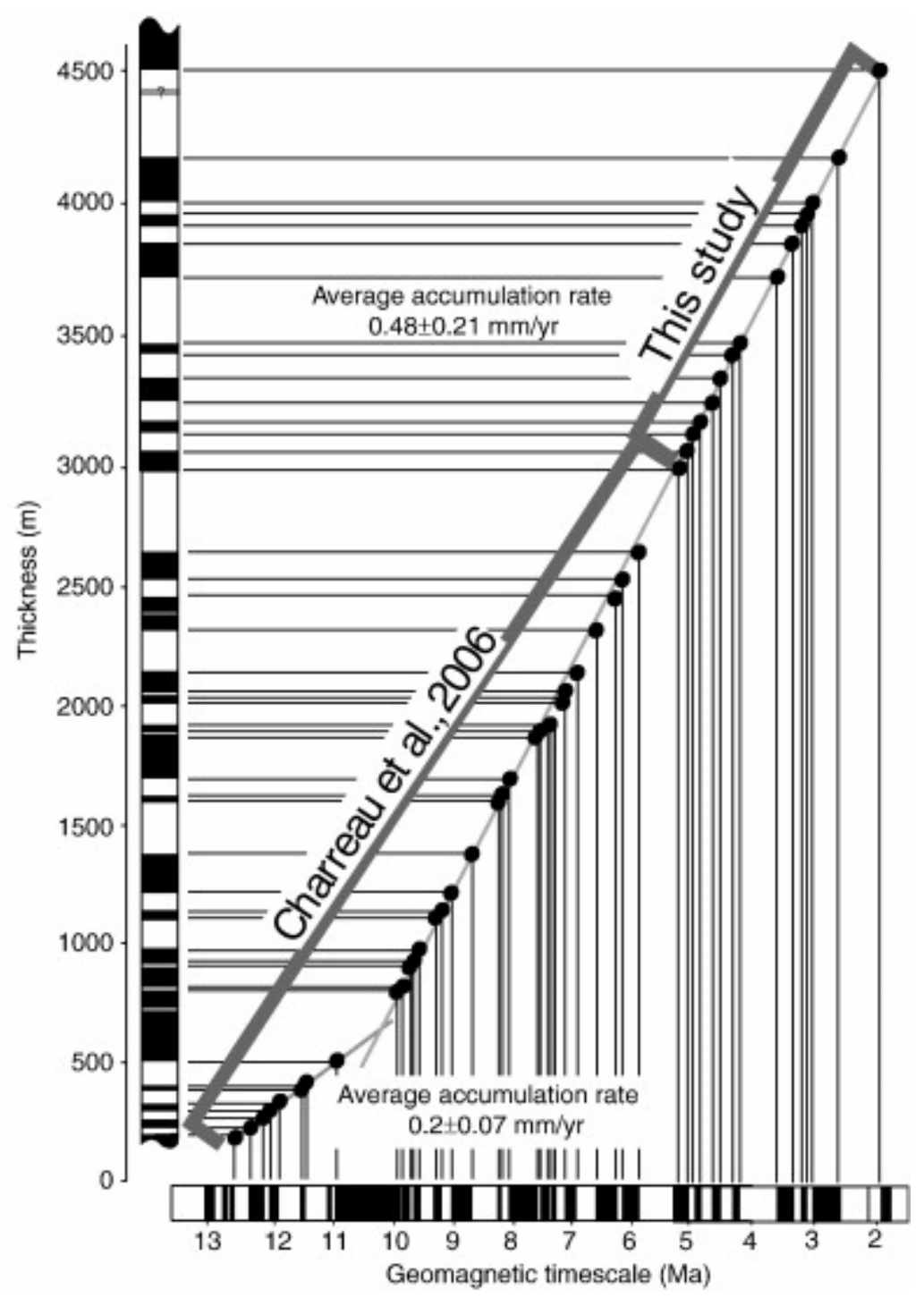

Fig. 7. Age versus depth plot of the total Yaha section, using data from this study and Charreau et al. (2006). 
a)

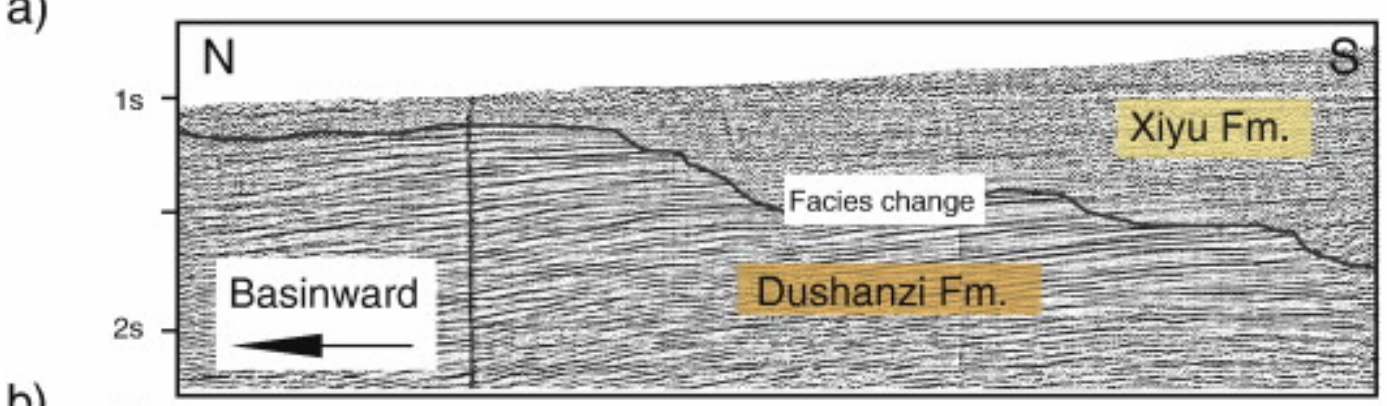

b)

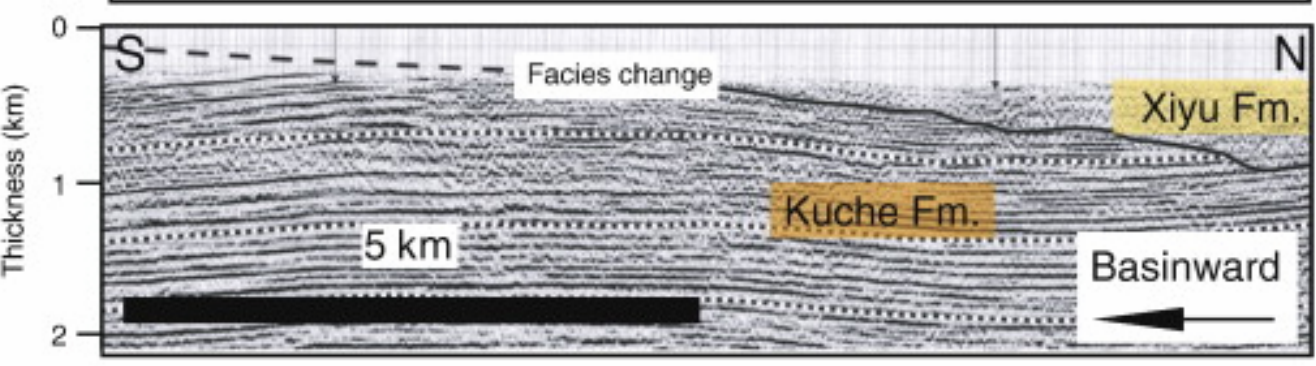

c)

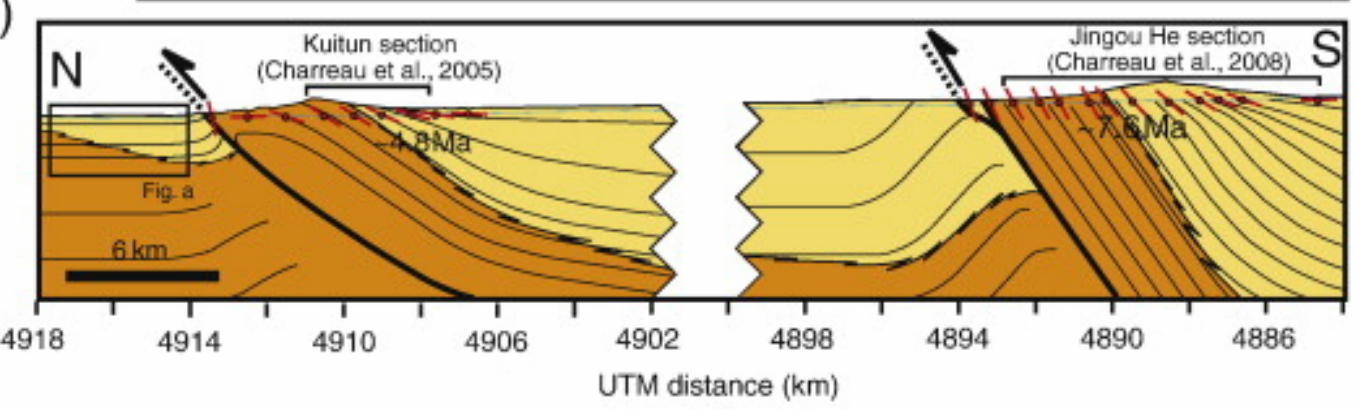

Fig. 8. (a) Seismic line across the Yakeng anticline (after (Hubert-Ferrari et al., 2005), see Fig. 1 for location) showing the basinward progradation of the Xiyu conglomerate above the more layered Kuche formation; (b) Seismic line North of the Dushanzi anticline in the Kuitun He river (for location see Fig. 1 and Fig. 8c) showing also the basinward progradation of the Xiyu conglomerate; (c) Cross section of the Dushanzi and Huerguosi anticline with location of the Jingou He and Kuitun magnetostratigraphic sections that provide constraint on the Xiyu basal age.

a)

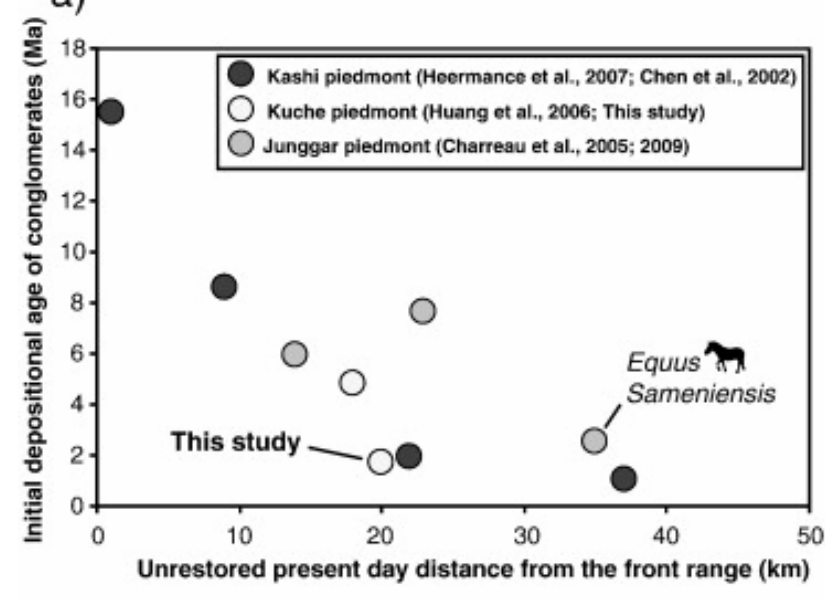

b)

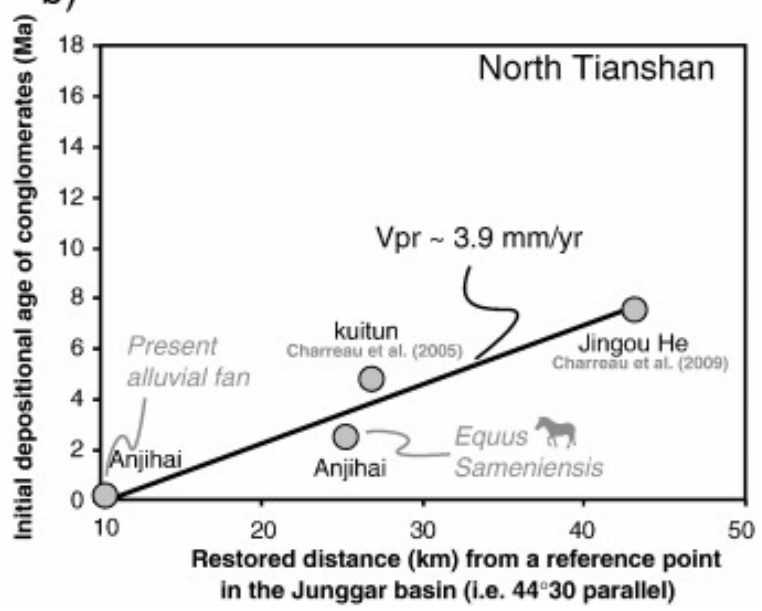

Fig. 9. (a) Plot of the initial depositional age of the Xiyu conglomerates against their present day distance from the front range. The front range is defined as the limit between Paleozoic rocks and Meso-Cenozoic foreland deposits, which probably represents old structures inherited from the Paleozoic orogeny within the Tianshan; (b) Plot of the initial depositional age of the Xiyu conglomerates found in the Northern Tianshan against their restored distance from the $\mathrm{N} 44^{\circ} 30^{\prime}$ latitude supposed fixed in the Junggar basin. 


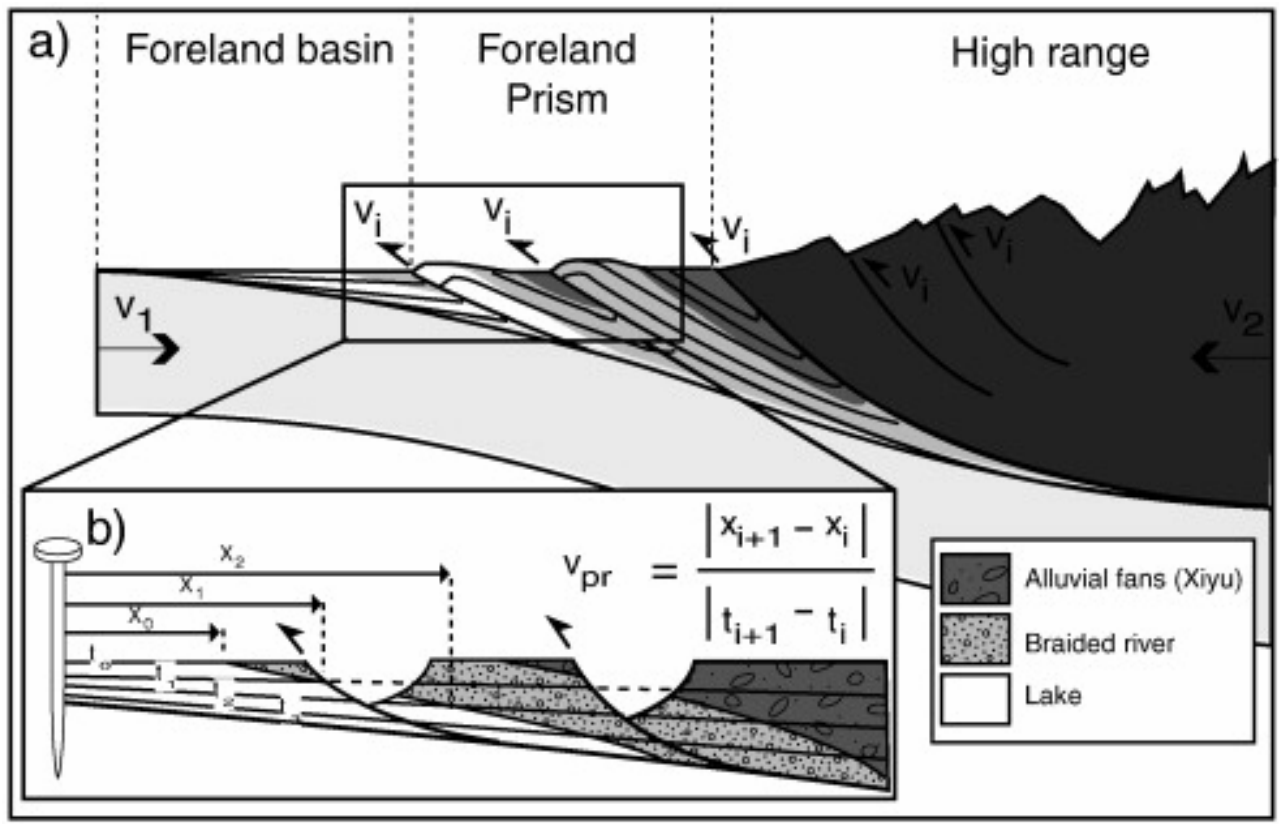

Fig. 10. (a) Schematic section of a half-range showing the relationship between sediment progradation rates, underthrusting rates and shortening across the structures that compose the piedmont and the range; (b) Schematic restored section of a piedmont from which one can estimate the sediment progradation rates of different facies. In both figures the Xiyu formation corresponds to the dark gray pattern within the foreland prism. 